NBER WORKING PAPER SERIES

\title{
POWERFUL INDEPENDENT DIRECTORS
}

\author{
Kathy Fogel \\ Liping Ma \\ Randall Morck \\ Working Paper 19809 \\ http://www.nber.org/papers/w19809 \\ NATIONAL BUREAU OF ECONOMIC RESEARCH \\ 1050 Massachusetts Avenue \\ Cambridge, MA 02138 \\ January 2014, Revised March 2021
}

We are grateful for helpful comments by Olubunmi Faleye, Wayne Lee, Tomas Jandik, Johanna Palmberg, Michael Weisbach, Jingxian Wu, Tim Yeager, seminar participants at Bentley University, Colegio de Estudios Superiores de Administración in Bogota, National University of Singapore, Oklahoma State University, Université Laval, University of Alberta, University of Arkansas, University of Illinois at Urbana-Champaign, University of New Hampshire, University of Nevada; and conference participants at the Board Options 2014 Seat at the Table Program, 2014 Boston Area Finance Symposium, 2014 Management Association, the Ratio Colloquium for Young Social Scientists, the Southern Finance Association 2013 meetings ("Outstanding Paper in Corporate Finance" award), Sunbelt XXXIV meeting of the International Network for Social Network Analysis Annual Conference; Financial Research Network Conference at the University of New South Wales. The authors gratefully acknowledge financial support from the Bank of Canada, Social Sciences and Humanities Research Council, National Science Foundation and Arkansas Science and Technology Authority, with resources managed by the Arkansas High Performance Computing Center. These are the views of the authors and do not necessarily reflect the views of the Bank of Canada or the National Bureau of Economic Research.

NBER working papers are circulated for discussion and comment purposes. They have not been peer-reviewed or been subject to the review by the NBER Board of Directors that accompanies official NBER publications.

(C) 2014 by Kathy Fogel, Liping Ma, and Randall Morck. All rights reserved. Short sections of text, not to exceed two paragraphs, may be quoted without explicit permission provided that full credit, including $\odot$ notice, is given to the source. 
Powerful Independent Directors

Kathy Fogel, Liping Ma, and Randall Morck

NBER Working Paper No. 19809

January 2014, Revised March 2021

JEL No. D85,G02,G3,G34,G38,K22,L2,Z13

\begin{abstract}
$\underline{\text { ABSTRACT }}$ challenging errant top managers, or both.

Kathy Fogel

Sawyer Business School

Suffolk University

Boston, MA 02108

kfogel@suffolk.edu

Liping Ma

Naveen Jindal School of Management

University of Texas at Dallas

Richardson, TX 75080

Liping.Ma@utdallas.edu

\author{
Randall Morck \\ Faculty of Business \\ University of Alberta \\ Edmonton, AB T6G 2R6 \\ CANADA \\ and NBER \\ randall.morck@ualberta.ca
}

Shareholder valuations are economically and statistically positively correlated with independent director power, gauged by a composite of social network power centrality measures. Powerful independent directors' sudden deaths reduce shareholder value significantly; other independent directors' deaths do not, consistent with powerful independent directors increasing firm valuations. Further tests associate more powerful independent directors with less value-destroying M\&A, less free cash flow retention, more CEO accountability, and less earnings management. We interpret these findings as more powerful independent directors better detecting and countering CEO missteps because of better access to information, greater credibility in 


\section{Introduction}

The statistical independence of legally independent directors is an ongoing puzzle in corporate finance (Adams et al. 2010; Adams 2017). Early work on independent directors (e.g. Weisbach 1988) justifies mandating more corporate directors be independent - that is, not dependent on the corporation except as directors. Independent directors seemed a sensible check on excessive CEO power, which directors who are employees, contractors, or close relatives of the CEO might be reluctant to provide. However, we find independent directors on corporate boards are unrelated to corporate performance measured by shareholder valuation (Q ratios) in data from 1998 through 2009, a period when shareholder valuation was widely accepted as the core objective of boards.

We posit that many independent directors become obedient servants to their CEOs, manifesting reflexive obedience to authority heuristic documented in social psychology (Milgram 1963) and neuroeconomics (Suen et al. 2014; Caspar et al. 2020). Confronted with pressure to make a decision, subjects obey authority figures - even authority figures issuing obviously unsound commands, such as Milgram's instructions to subjects to electrocute people.

Obedience to authority is an example of what Kahneman (2011) calls thinking fast, a behavioral response that leads often enough to ex-post acceptable decisions, as opposed to thinking slow, the economically and metabolically costly calculation of outcomes and probabilities in economics. Kahneman (2011) posits that people default to thinking fast; but activate thinking slow if thinking fast fails to converge. Milgram (1975) reports subjects' obedience to a questionable authority figure ceasing entirely if a credible rival authority figure enters and voices dissent.

We hypothesize that independent directors who are more credible as rival authorities to the CEO might better activate thinking slow in boards. We test this hypothesis by mapping out a social network of officers and directors based on their current and past service at different companies. We assign each director a composite power measure constructed from four power centrality measures used in social psychology (degree, closeness, betweenness, and eigenvector centrality). Each captures a different dimension of an individual's social power, but all are associated with greater access to information and greater social influence. We deem a director powerful in a given year if she falls within the top quintiles of at least three of these measures' cross-sectional distributions for that year.

Our baseline regressions associate a powerful independent board (a majority of directors independent and a majority of these powerful) with a 6.58\% higher Tobin's Q in 1998 through 2009, when shareholder value maximization was widely accepted as good corporate governance. Powerful independent director sudden deaths correspond to statistically and economically significant immediate share price drops, consistent with shareholders viewing powerful independent directors as causing higher valuations. Further tests associate powerful independent boards with corporate actions more in accord with shareholder value 
maximization. Firms with powerful independent boards do less value-destroying M\&A, retain less free cash flow, oust more CEOs after poor performance, and manipulate earnings less.

These results are highly robust to plausible alternative variable definitions, econometric specifications, and sample construction methodologies. They also elaborate, rather than contradict, prior work on director characteristics. Higher valuations are associated with independent directors being less busy (Rerris et al. 2003; Fich and Shivdasani 2006; Hauser 2018), less distracted (Masulis and Zhang 2019), more intense monitors (Faleye et al. 2011), more experienced (Kang 2013), and more invested in the firm's equality (Bhagat and Bolton 2013). Including these variables alongside leaves our independent director power measures unaffected, suggesting independent director power is a characteristic of independent importance. However, the explanation we posit might apply independently to these variables if busier and more distracted independent directors rely more on thinking fast to get through meetings faster. Moreover, independent directors more intensely involved with the firm or more invested in its shares might, like more powerful independent directors, have more credibility challenging the CEO. Ferris et al. (2011) link elevated valuations to celebrity independent directors. Celebrities, by definition, have high social power, and perhaps credibility in questioning CEOs. Conflicting findings on diversity-augmenting independent directors (e.g. Ahern and Dittmar 2012; Kim and Starks 2016) might reflect director power as a latent factor. Ngyuen and Nielsen's (2010) finding that share prices fall on news of independent directors' sudden deaths is persuasive evidence that director independence matters. We find large significant negative abnormal returns on powerful independent directors' sudden deaths only and insignificant abnormal returns on the sudden deaths of non-powerful independent directors, suggesting powerful independent director sudden deaths are important to their result.

Our results suggest boards dominated by powerful independent directors elevate shareholder value. During the period we study, 1998 through 2009, good governance was associated with shareholder value maximization. The 2010s saw stakeholder rights, corporate social responsibility, and the like emerge as alternative definitions of good governance. These changes might cause our methodology to lose traction because they render good governance harder to measure. However, our conclusion that independent directors better able to interrupt a board's reflexive obedience to a possibly errant CEO improve corporate governance is likely to remain valid, whatever the definition of good governance.

\section{The Function of Independent Directors}

\subsection{Selection for Agreeability}

Fama (1980) argues independent directors who better contribute to maximizing shareholder value are more valuable and more sought after as directors. Independent directors tied to corproate shipwrecks indeed hold fewer subsequent directorships and court personal liability (Srinivasan 2005; Fich \& Shivdasani 2007; Fos 
\& Tsoutsoura 2014; Brochet \& Srinivasan 2014). However, literature reviews (e.g. Adams 2017) reaffirm Hermalin and Weisbach's (2003) assessment "there does not appear to be an empirical relationship between board composition and firm performance."

If all firms maximized shareholder value, no cross-sectional relationship would exist between governance characteristics and valuation (Demsetz \& Lehn 1985). However, correlations between valuation and other aspects of governance are evident (Yermack 1996; Gompers et al. 2003; Faleye 2009; Bebchuk et al. 2009; Bhagat \& Boulton 2013; and others), suggesting different firms balance shareholder value maximization and insider utility maximization in different proportions (Jensen \& Meckling 1976; Hermalin \& Weisbach 1998).

Utility maximizing entrenched managers would curtail the actual independence of legally independent directors. Mace (1986, p. 99) quotes CEOs explaining their preferences for directors who are "friendly, if you will" and "non-boat-rockers", and defending "selecting outside directors ... much like a trial lawyer goes about the selection of a jury”. Mace (1986) quotes a depiction of an ideal director thus:

"I have one friend that's just greatest agreer that there ever was, and he is on a dozen boards. I know other fellows that have been recommended to some of the same companies as directors, but have never gotten anywhere on the list to become directors. Because if a guy is not a yes man - no sir, he is an independent thinker - then they are dangerous to the tranquility of the board room. Company presidents are afraid of them - every damn one of them."

Higgs (2003, p. 39) reports British independent directors tend to be friends of the CEO who also satisfy legal tests of independence

"Almost half of the non-executive [independent] directors surveyed ... were recruited to their role through personal contacts or friendships. Only 4\% had had a formal interview, and 1\% had obtained their job through answering an advertisement. This situation ... can lead to an overly familiar atmosphere in the boardroom."

Bebchuk and Fried (2006) view the US situation similarly. Regulations and best practice guidelines fill boards with legally independent directors, but if selected for obedience to the CEO, these are unlikely to challenge an errant CEO.

\subsection{Basis for a Behavioral Finance Interpretation}

Milgram (1963, 1965, 1975) highlights obedience to authority as a readily triggered human response. Milgram sat subjects before a console of switches marked 15 volts, 30 volts, 45 volts, etc. up to 450 volts with wires running to the body of an actor (falsely) identified as the experimental subject. Milgram explained (falsely) the experiment was to see if people learned faster if punished for mistakes. Milgram asked the actor a questions; the actor replied with scripted answers, and after each wrong answer, Milgram, instructed the true subject (operating the console) to apply a higher voltage shock to the actor, who feigned 
increasing pain. The experiment's true purpose was to see if true subjects electrocuted others as ordered to.

Figure 1 summarizes. All subjects exhibited obedience up to 150 volts, when the actor was scripted to cry out in pain. Thereafter, $80 \%$ exhibited obedience up to 300 volts, when the actor refused to answer and pled to be let out. Roughly two third of subjects exhibited obedience up to the maximum, despite the words "danger, severe" and "XXX" above those switches. These results are widely replicated and robust across genders, ages, social classes, and nationalities (Miller 1986; Merritt and Helmreich 1996; Tarnow 2000; Blass 2004, 2012; Packer 2008; Miler 2016; Doliński et al. 2017). Milgram concluded humans have an innate obedience to authority response, as Darwin's (1871) proposed would arise from natural selection: "a tribe including many members who, from possessing in a high degree the spirit of patriotism, fidelity, obedience, courage, and sympathy, were always ready to give aid to each other and to sacrifice themselves for the common good, would be victorious over other tribes; and this would be natural selection."

Evolutionary biology models also imply intense group-level natural selection for in-group self-sacrifice if between-group warfare is deadly (Wilson 2012), as between early hunter gatherer bands (Pinker 2012).

Milgram drew intense fire for encouraging unethical sadism; though subjects also obeyed orders to inflict blasts of noise labeled "permanent hearing damage" on subjects and themselves (Martin et al. 1976). University research ethics committees shut down replications for several decades; but recently permitted replications using virtual reality (e.g. Slater et al. 2006; Dambrun and Vatine 2010; Mermillod et al. 2015) or much lower voltages (Dolinski et al. 2017) that affirm Milgram's findings.. Criticism resumed, accusing Milgram of downplaying disobedience, explaining Nazi atrocities and using methodology not up to modern standards (Perry 2013). These criticisms reveal no data manipulation in his archived notes (Bregman 2013) refute none of his basic findings (Miller 2016). Miller (2016) suggests the Naturalistic Fallacy (what is natural must be good) motivates the criticism. Romm (2015) quotes Miller: "critics of Milgram seem to want to - and do-find material in these archives that makes Milgram look bad or unethical or, in some cases, a liar," but although "people have tried to knock it down, [his work] always comes up standing."

In fact, Milgram had rejected unethical sadism as an explanation because, in exit interviews, virtually every subject indicated disobedience as morally right, yet few disobeyed. Asked why they obeyed, subjects evoked loyalty, duty honor; fulfilling expectations, and not making a scene. Milgram (1974, p. 8) therefore posits an agentic shift:

"the essence of obedience consists in the fact that a person comes to view themselves as the instrument for carrying out another person's wishes, and they therefore no longer see themselves as responsible for their actions. Once this critical shift of viewpoint has occurred in the person, all of the essential features of obedience follow" 
This agentic shift does not suppress ethical consideration, but redirects them (Milgram 1975, pp. 7-8)

"The typical subject did not lose his moral sense; instead, it acquires a radically different focus. He does not respond with a moral sentiment to the actions he performs, Rather, his moral concern now shifts to a consideration of how well he is living up to the expectations that the authority has of him."

Milgram (1974, p. 145-6) explains that

"The most far-reaching consequence of the agentic shift is that a man feels responsibility to the authority directing him, but feels no responsibility for the content of the actions that the authority prescribes."

In the terminology of moral philosophy, Milgram's agentic shift is deontological (duty-focused) ethics displacing teleological (outcome-focused) ethics. In contrast, Jensen and Meckling's (1976) agency problem is utility maximizing (outcome-focused) agents neglecting their duty to shareholders.

A behavioral finance interpretation of Milgram's findings drafts Kahneman's (2011) distinction of thinking fast, reflexive responses such as "obey authority", from thinking slow, rationally weighing likelihoods and outcomes, and shows thinking fast governs most decisions. This is boundedly rational (Simon 1997) if errors from thinking fast cost less than the information collection and analysis (Bikhchandani et al. 1992; Masulis and Mobbs 2014) and mental effort (Baumeister et al. 1998; Hirsch et al. 2021) thinking slow requires. Kahneman (2011) concludes thinking slow activates only if thinking fast fails to converge on a response.

That obedience to authority is a form of thinking fast is most evident in Milgram's (1975) runs in which a second psychologist enters at the 150 volt threshold, criticizes the experiment, and leaves (dashed line in Figure 1). Obedience to authority no longer converges because two credible authority figures disagree. Metabolically costlier thinking slow activates (Suen et al. 2014; Caspar 2020), subjects weigh the costs and benefits of electrocuting people, and obedience ceases. ${ }^{1}$ A second subject voicing dissent elicits a smaller decrease in obedience (dotted line in Figure 1), consistent with a less credible dissenter disrupting reflexive obedience less effectively.

We posit the presence of a credible rival authority might likewise interrupt directors' reflexive obedience to CEOs; and that independent directors with greater social power might be more credible rival authorities. Mace (1986, p. 186) quotes directors explaining falling into line behind the CEO "to avoid looking like an idiot." More socially powerful independent directors have more, deeper, more pivotal and

1 Neuroeconomics research shows that hearing voiced disagreement activates subjects' prefrontal cortex, a brain region associated with deliberative problem solving (thinking slow); whereas voiced agreement activates sensory brain areas, consistent with thinking fast (Suen et al 2014; Hirsch et al. 2021). Burger (2009) fails to replicate this disobedience effect, but uses shocks only up to 150 volts and assure subjects the shocks are not dangerous. 
denser networks of connections, so they have more information and influence and therefore less fear of "looking like an idiot," as do other directors forced to choose whom to fall into line behind.

Institutions formalizing opposition arise in many contexts (Morck 2008). Parliamentary democracies charge a Leader of the Official Opposition with publicly opposing the Prime Minister's policies, even if the same policies would prevail were their roles reversed; and other democracies have analogs. Democracies also provide better public goods than do one-party states (Deacon 2009). In common law courts, the Adversary System pits rival lawyers against each other before a judge and jury, who render verdicts. In Napoleonic Civil Code courts, an Investigating Magistrate directs police, organizes evidence, summons witnesses, and renders verdicts. La Porta et al. (2008, p. 285) report a "superior performance of common law in many [despite its] high costs of litigation and well-known judicial arbitrariness." In the $20^{\text {th }}$ century, successive academic areas took to using referees and discussants (Baldwin 2017). Institutions that selectively elicit disagreement between rival authorities might activate Kahneman's (2011) thinking slow in parliaments and electorates, judges and juries, and journal editors and researchers. Each can work badly; but perhaps less badly than known alternatives. We interpret our findings as powerful independent boards serving as a loyal opposition to CEOs and activating thinking slow when good governance requires it.

\section{Data and Variables}

\subsection{Social Network Data}

A social network represents each of $N$ individual as a node and each connection between two individuals as a line segment connecting their nodes. We use 1998 through 2009 BoardEx data to construct annual social networks, whose nodes represent the 305,904 top executives and directors of 5,947 listed US firms. We infer a connection between two individuals if they ever served as a director or top executive at the same firm in the same year. Once a connection forms, we assume it persists. Formally, this makes the network a one-mode network: once lines form, they are permanent. ${ }^{2}$ As a result, the network grows monotonically from 191,049 nodes and 5,438,006 connections between nodes in 1998 to 313,958 nodes and 11,639,006 connections in 2009. ${ }^{3}$ To control for this, our assessments of an individual's social power centrality each year reflect her position in the cross-sectional distribution of that measure that year.

About $75 \%$ of connections are identified from BoardEx; the rest are from computerized matching of itemized job histories in BoardEx Director Work History data. The second step is necessary because random inspection revealed prominent business leaders missing without it. The network excludes nonbusiness connections, such as shared alma maters, ethnicity, hometowns, or other common experiences

2 Appendix section A2 rebuilds the network in various ways: dropping links from fewer than three years of overlapping appointments, that were formed five or more years ago, or both. These exercises generate qualitatively similar to those in the tables.

3 Appendix Table A1 provides details. 
because Chidambaran et al. (2012) find non-business ties qualitatively different from business connections. Another reason for using only business connections is that the data, from proxy statements and annual reports, are objective, comparable across individuals, and free of self-selection bias. A potential cost is that our representation of the network may miss many connections in individuals' true (unobservable) networks. Also, we cannot tell if connected individuals talk daily, every ten years, or are not on speaking terms.

Compustat data are matched to RiskMetrics data by CUSIP and year. Individuals in the social network are matched to RiskMetrics by firm GVKEY and year, then by first and last names. This yields a 132,020 individual-year panel of officers and directors of S\&P 1500 firms. Names are matched electronically, double-checked (concatenating names and sorting by distance) to flag near misses, then checked by manually examining all non-matches to correct for nicknames and other name variant forms. Each panel observation contains RiskMetrics data for that year on the individual's position, legal independence, committee memberships, and other characteristics alongside her power centrality measures.

\subsection{Power Centrality Measures}

Social network theory (Milgram 1967; Proctor \& Loomis 1951; Sabidussi 1966; Bonacich 1972; Freeman 1977, 1978; Watts \& Strogatz 1998) provides measures of the power centrality of each individual in such a network. These are intuitively plausible and empirically validated (Padgett \& Ansell 1993; Banerjee et al. 2013) measures of social power. For each individual, we calculate four power centrality measures each year. We combine all four to construct a composite power measure that we posit reflects strength of standing to voice credible dissent in board meetings.

The simplest of these social power centrality measures is the number of people with which an individual is directly connected. Individual $i$ 's degree centrality in year $t$ is

$$
D_{i, t}=\sum_{j \neq i} x_{i j, t}
$$

where $x_{i, j, t}=1$ if individuals $i$ and $j$ have a connection as of year $t$, and 0 otherwise. Thus, $D_{i, t}$ is an integer between 0 and $N_{t}-1$, with $N_{t}$ the number of nodes in the network in year $t$. A director with more direct connections has more direct sources of information and more direct contacts to influence. We term this the breadth of her social power.

Our next two social power measures are built from Milgram's (1967) degrees of separation, or geodesic distance, between individuals. If $i$ is directly connected with $j$ in year $t$, the geodesic distance separating them is $g_{i, j, t}=1$. If $i$ is not directly connected to $j$, but is connected with $k$, who is connected with $j$, then the shortest path from $i$ to $j$ is $i$ to $k$ to $j$, which has two links, so $g_{i, j, t}=2$. The geodesic distance between two individuals is the number of links in the shortest path connecting them. Shortest paths need not be unique, but geodesic distance is unique.

Our second social power centrality measure is closeness centrality. In a complete network (every 
individual is connected to every other individual by some chain), individual $i$ 's closeness centrality in year $t$ can be defined

$$
C_{i, t}^{\prime}=\frac{N_{t}-1}{\sum_{i \neq j} g_{i j, t}}
$$

That is, an individual's $C_{i, t}^{\prime}$ is the inverse of her geodesic distance from the other $N_{t}-1$ individuals in the social network. A tweak to [2] is necessary because our network is incomplete: it contains some small subnetworks unconnected to the rest of the network. Setting the shortest distance between unconnected nodes to $g_{i j, t}=\infty$ is untenable because a single infinite $g_{i j, t}$ in the denominator of [2] sets $C_{i, t}^{\prime}$ to zero. Excluding infinite $g_{i j, t}$ is also problematic. Individual A in a small network might have a much higher closeness than individual B in a large network, but A might have less power than B, whose influence extends across more people. As an extreme case, consider a sub-network with two connected individuals. Dropping all unconnected nodes leaves each with the highest possible closeness of one; yet they have negligible social influence because they are unconnected to the remaining $300,000+$ people.

To account for this, we modify [2] to define closeness centrality as

$$
C_{i, t}=\frac{N_{t}-1}{\sum_{i \neq j} g_{i j, t}} \times \frac{n_{t}}{N_{t}}
$$

where $n_{t}$ is the size of the connected sub-network individual $i$ belongs to in year $t$, and $N_{t}$ is the total number of individuals in the entire network that year. This modification rescales $C_{i, t}$ by the size of each individual's connected subnetwork to more accurately reflect her overall social power. We posit that a lower mean degree of separation from other officers and gives an individual readier access to their information and more potential to influence them and that individuals in a larger connected subnetwork have more social power than those in smaller connected subnetworks, all else equal. We characterize this as the depth of an individual's social power.

Our third social power centrality measure is an individual's betweenness centrality, the fraction of the $1 / 2\left(N_{t}-1\right)\left(N_{t}-2\right)$ geodesics linking pairs of other individuals in the network in year $t$ that go through her. For every possible triplet of individuals $i, j$ and $k$ in year $t$, define the indicator

$$
m_{j, k, t}(i)= \begin{cases}1 & \text { if } i \text { is a node on a geodesic linking } k \text { and } j \\ 0 & \text { otherwise }\end{cases}
$$

The betweenness centrality of individual $i$ in year $t$ is

$$
B_{i, t}=\sum_{j<k, i \neq j, i \neq k} \frac{m_{j, k, t}(i) / m_{j, k, t}}{\frac{1}{2}\left(N_{t}-1\right)\left(N_{t}-2\right)}
$$

where $m_{j, k, t}$ is the number of geodesics linking $j$ and $k$ that year. Dividing by $m_{j, k, t}$ adjusts for cases where more than one geodesic connects $j$ and $k$. Intuitively, a higher $B_{i, t}$ makes an individual more important to the connections of others, and thus more able to influence the movement of information and actions others 
(Watts and Dodds 2007; Burt 2009). ${ }^{4}$ We term this the acuity of the individual's social power.

Our fourth power centrality measure, eigenvector centrality $\left(E_{i, t}\right)$ is recursively calculated. Individual $i$ 's eigenvector centrality is her importance, weighed by the similarly calculated importance of all her direct contacts, each weighted by the importance of their direct connections, and so on. More formally, assume the existence of this measure for person $i$ in year $t$, and denote it $E_{i, t}$. In matrix notation, with the vector of individuals' eigenvector centralities $\mathbf{E}_{t} \equiv\left[E_{1, t}, \ldots E_{i, t}, \ldots E_{N, t}\right]$, the recursions collapse into the condition that $\lambda_{t} \mathbf{E}_{t}{ }^{\prime} \mathbf{E}_{t}=\mathbf{E}_{t}{ }^{\prime} \mathbf{A}_{t} \mathbf{E}_{t}$. Thus, $\mathbf{E}_{t}$ is an eigenvector of the matrix of connections $\mathbf{A}_{t}$, and $\lambda_{t}$ $i s$ its associated eigenvalue. To ensure that $E_{i, t} \geq 0$ for all individuals, the modified Perron-Frobenius theorem is invoked, and the eigenvector centrality values of the individuals in the network are taken as the elements of the eigenvector $\mathbf{E}_{t}^{*}$ associated with $\mathbf{A}_{t}{ }^{\prime}$ s principal eigenvalue, $\lambda_{t}^{*}$. Repeating this exercise for each individual each year generates the individual-year panel variable $E_{i, t}$. An individual with higher eigenvector social power is connected to others which higher social power, which reflects their connections to others with higher social power and so on. Eigenvector power centrality can be interpreted as measuring how pervasive an individual's social power is (Elliott and Golub 2019).

These four power centrality measures are meaningful in a wide range of situations, though their interpretations vary (Hanneman and Riddle 2005, c. 10). In general, individuals with higher social power have broader, deeper, more acute and more pervasive ways of gaining information, passing information along, and influencing others. All plausibly mitigate costs of challenging errant CEOs.

To make the centrality measures comparable with each other and over time, we rank the raw values of each for all individuals each year and assign a percentile value from 1 to 100 to each individual's centrality measures each year. Thus, regardless of how the size of the network varies over time, a person with a higher percentile is more centrally positioned in the network than a person with a lower value. We denote these normalized rank-transformations of $D_{i, t}, B_{i, t}, C_{i, t}$, and $E_{i, t}$ as $d_{i, t}, b_{i, t}, c_{i, t}$, and $e_{i, t}$ respectively.

Table 1 presents summary statistics for the power centrality measures of all S\&P 1500 officers and directors. These individuals tend to be highly powerful within to overall social network. Panel A summarizes the raw power centrality measures: $D_{i, t}, B_{i, t}, C_{i, t}$, and $E_{i, t}$. Their mean betweenness of $0.00973 \%$ means the typical director sits on about one in ten thousand shortest paths between pairs of other individuals in the full network (top executives and directors at all firms). Note that, even within the S\&P 1500, the distribution is skewed: the mean exceeds the $75^{\text {th }}$ percentile and the maximum is $0.677 \%$; so the most powerful person is on one of every 150 shortest paths between all pairs of other top managers and directors. The typical S\&P 1500 director's mean closeness is $25.3 \%$, indicating he is about four $(1 / 0.253=3.94)$ degrees of separation from any other randomly chosen top manager or director. The median degree

$4 \quad$ Padgett and Ansell (1993) use high betweenness to explain Medici dominance in $15^{\text {th }}$ century Florence: other elite families were generally connected to each other only via the Medici. 
centrality of 197 indicates that the median S\&P 1500 director has direct ties with 197 other individuals in the network. Raw eigenvector centralities are not amenable to intuitive explanation.

Panel B of Table 1 presents analogous summary statistics for S\&P 1500 firm officers and directors' percentile social power measures: $d_{i, t}, b_{i, t}, c_{i, t}$, and $e_{i, t}$. The means of all four measures are in their top quartiles. Thus, S\&P 1500 directors are more powerful on average than are officers and directors in general - the larger sample used to construct individuals' percentile scores. Still, all four measures range from the lowest or second-lowest to the top percentile, so S\&P 1500 directors span the full range from negligible to paramount social power.

S\&P 1500 CEOs and non-CEO chairs (not shown) are similarly more powerful than the average top manager or director and likewise span the full range from slight to dominant social power. The mean social power measures of S\&P 1500 directors uniformly exceed those of S\&P 1500 CEOs, regardless of the power centrality measure used. Directors who chair the board have uniformly higher mean power centrality than directors in general.

\subsection{Identifying Powerful Independent Directors}

We define a director as an independent director (ID) of a firm if she is so designated in the firm's SEC filings in RiskMetrics data. The legal definition of an independent director mandates "'no material relationship' with the listed company, either directly or as a partner, shareholder or officer of an organization that has a relationship with the company." Note that an individual's independence is a firm-dependent individual-level variable. A person can be an independent director on one firm's board and a nonindependent director on another's board.

We define an individual as powerful in terms of a centrality measure in a given year if her value in that measure lies within the top quintile of its empirical distribution across the full network of top managers and directors. To operationalize this, we define an individual-year dummy using each percentile centrality measure. We set each dummy to one if the individual falls in the top quintile of that measure's distribution that year, and to zero otherwise. Thus,

$$
\delta\left(d_{i, t} \geq 80\right)= \begin{cases}1 & \text { if } d_{i, t} \geq 80 \\ 0 & \text { otherwise }\end{cases}
$$

and define $\delta\left(b_{i, t} \geq 80\right), \delta\left(c_{i, t} \geq 80\right)$, and $\delta\left(e_{i, t} \geq 80\right)$ analogously.

We combine the four power centrality measures to make composite individual-level social power measures. Table 1 Panel $\mathrm{C}$ presents the correlation matrix of the centrality measures across all S\&P 1500 CEOs, non-CEO chairs, and directors. The four measures are highly correlated, with correlation coefficients averaging $64 \%$ and statistical significance under 0.01 . Typical in this regard is Jeffrey Garten, who served

5 New York Stock Exchange Listed Company Manual 303A.02: Independence Tests. 
at Blackstone and Lehman Brothers, and has high centrality by all four measures. His mean $d_{i, t}$ over the sample period is at the $94^{\text {th }}$ percentile, his mean $b_{i, t}$ is at the $98^{\text {th }}$, his mean $c_{i, t}$, and $e_{i, t}$ are both at the $93^{\text {rd }}$ percentile. This highly positive correlation justifies using the means of the four measures as in individuallevel general social power measure.

However, the four measures sometimes disagree. Inspection shows these cases are often individuals with a small number of connections that include a few extremely powerful people. In such cases, low degree power centrality (few direct connections) and low betweenness power centrality (she is an endpoint in most geodesics that contain her) accompany high closeness power centrality (her powerful connections put her only a few links away from many other people) and high eigenvector power centrality (her connections are powerful, as are theirs, and so on) centrality. For example, Ray Wilkins Jr., a director at H\&R Block in 2000 , ranked in the $83^{\text {rd }}$ percentile by closeness and the $88^{\text {th }}$ by eigenvector centrality, but only in the $66^{\text {th }}$ percentile by degree centrality and the $68^{\text {th }}$ by betweenness centrality. He is therefore not a PID in 2000 (though he does attain PID status subsequently).

The highest correlation for directors in Table 1 Panel $\mathrm{C}$ is between percentile closeness power centrality and percentile eigenvector power centrality $(\rho=0.94)$, the same pattern evident above. Moreover, betweenness correlates best with degree centrality $(\rho=0.81)$. However, individuals' power measures are not cleanly split along these lines, for degree centrality correlates most highly with closeness centrality.

Power centralities can be interpreted as gauging access to information (Freeman 1978; Freeman et al. 1979; Hossain et al., 2007; Kiss and Bichler 2008). If so, degree power centrality assumes information decays completely after one degree of separation (Bolland 1988), while closeness and eigenvector power centralities let information decay as degrees of separation increase. Betweenness power centrality captures the number of potentially distinct information flows the individual can tap. Power centralities can also be interpreted as gauging power to influence others. Borgatti (2006) links closeness to control over information progogation and betweenness to control over information flow between others. Lee et al. (2010) argue betweenness best captures "power as influence." Degree power centrality, the number of one's direct connections, likewise counts the number of people one can directly influence. Closeness and eigenvector measures potentially then capture how important influencing one's contacts is to influence others. We hypothesize that a composite of these different dimensions of social power best captures an independent director's credibility as a rival authority figure to the CEO.

Also, sampling omissions can destabilize some measures more than others (Borgatti et al. 2006; Costenbader and Valente 2003, 2004) find degree centrality the most stable and eigenvector centrality the least stable. Because we may well miss some links between individuals in this network, sampling omission problems also motivate combining the four measures into a composite.

We therefore follow Hossain et al. (2007) and construct composite social power measures for each 
individual each year. The main measure used in the tables is a dichotomous composite social power measure

$$
P D_{i, t}= \begin{cases}1 & \text { if } \delta\left(d_{i, t} \geq 80\right)+\delta\left(b_{i, t} \geq 80\right)+\delta\left(c_{i, t} \geq 80\right)+\delta\left(e_{i, t} \geq 80\right) \geq 3 \\ 0 & \text { otherwise }\end{cases}
$$

defining individual $i$ as powerful in year $t$ if three or more of her power centrality measures fall into the top quintiles of their distributions in year $t .^{6}$ If the individual is both powerful $\left(P D_{i, t}=1\right)$ and an independent director of a given firm that year, she is a powerful independent director $(P I D)$ at that firm that year.

Some tables and robustness checks use a continuous composite social power measure, the mean of her three highest power centrality percentile measures,

$$
p_{i, t}=\frac{1}{3}\left(b_{i, t}+c_{i, t}+d_{i, t}+e_{i, t}-\min \left[b_{i, t}, c_{i, t}, d_{i, t}, e_{i, t}\right]\right)
$$

The two measures yield identical patterns of signs and significance, so the tables primarily use the indicator. ${ }^{7}$

\subsection{Identifying Powerful Independent Boards}

Aggregating to the firm-level, we designate firm $h$ 's board as an independent board (IB) in year $t$ if a majority of its directors are listed as independent directors in its disclosure documents, and define the firmyear indicator variable

$$
I B_{h, t}= \begin{cases}1 & \text { if a majority of firm } h \text { 's board are independent directors in year } t \\ 0 & \text { otherwise }\end{cases}
$$

We then set the firm-level indicator variable $P I N_{h, t}$ to one if a majority of firm $h$ 's independent directors are PIDs that year and to zero otherwise:

$$
P I N_{h, t}= \begin{cases}1 & \text { if a majority of firm } h \text { 's independent directors are PIDs in year } t \\ 0 & \text { otherwise }\end{cases}
$$

The product of these is a third firm-level indicator defining a firm as having a powerful independent board (PIB) if a majority of its directors are independent and a majority of these are powerful

$$
P I B_{h, t}=I B_{h, t} \times P I N_{h, t}
$$

The alternative continuous firm-level measure of independent director centrality,

$$
I D C_{h, t}=\frac{1}{H_{h, t}} \sum_{i=1}^{H_{h, t}} p_{i, t}
$$

is the mean across all $H_{h, t}$ of firm $h$ 's independent directors in year $t$ of the composite power centrality measure, $p_{i, t}$, in [8]

6 All four of centrality measures for $39.7 \%$ of directors in firms used in the tables fall in the top quintiles of distributions based on all network nodes. This sample thus contains a disproportionate fraction of powerful directors. All four measured also tend to be high in unison. For example, only $6.7 \%$ of the directors in our sample make the top quartiles in only $B_{i}, C_{i}$ and $D_{i}$; only $2 \%$ do so in only $B_{i}, C_{i}$ and $E_{i}$; and a mere $1 \%$ do so in only $B_{i}$, $D_{i}$ and $E_{i}$.

7 The results are robust to reasonable alternatives to [7] and [8], including cutoffs slightly different from $20 \%$, requiring all four individual measures to be in their top $20 \%$, the means of all four measures, and first principal component values. See Appendix Section A2 for further details and additional robustness checks. 
We say a firm has a non-CEO chair and set the indicator $N C C_{h, t}$ to one if firm $h$ 's CEO does not chair its board that year, and to zero otherwise. To indicate whether or not firm $h$ has a powerful non-CEO chair, we define

$$
P N C_{h, t}= \begin{cases}1 & \text { if individual } i \text {, not its CEO, chairs } h^{\prime} \text { s board in year } t \& \text { has } \\ \delta\left(d_{i, t} \geq 80\right)+\delta\left(b_{i, t} \geq 80\right)+\delta\left(c_{i, t} \geq 80\right)+\delta\left(e_{i, t} \geq 80\right) \geq 3 & \text { otherwise }\end{cases}
$$

Thus, firm $h$ has a powerful non-CEO chair if the chair is powerful, in that at least three of her four centrality measures fall into the top quintiles of their distributions, and is not the CEO.

As a continuous analog of [13], we use the mean of the chair's top three individual power centrality measures, her $p_{i, t}$, if she is not also the CEO. We denote this firm-level variable $N C C C_{h, t}$, and set it to zero if the CEO chairs the board.

Finally, we analogously identify a firm as having a powerful CEO (PCEO) in year $t$ if three or more of its CEO's four centrality measures fall within the top quintiles of their individual-level distributions that year. Thus, we define

$$
P C E O_{h, t}= \begin{cases}1 \quad & \text { if } h^{\prime} \text { s CEO in year } t \text { is individual } i, \text { who has } \\ \delta\left(d_{i, t} \geq 80\right)+\delta\left(b_{i, t} \geq 80\right)+\delta\left(c_{i, t} \geq 80\right)+\delta\left(e_{i, t} \geq 80\right) \geq 3 & \\ 0 \text { otherwise }\end{cases}
$$

We also use the mean of the CEO's three highest power centrality measures, her $p_{i, t}$, and denote this firmlevel variable $C E O C_{h, t}$. The S\&P 1500 CEOs' mean composite social power is the $74^{\text {th }}$ percentile of the individual-level distribution of composite social power; their median is the $80^{\text {th }}$. Table 2 lists and defines variables used in the tables below.

For each year from 1998 to 2009, Table 3 tallies fractions of firms with majority independent boards and powerful independent boards, fractions of firms that separate the CEO and chair jobs, and fractions of firms that appoint a powerful director as the non-CEO chair. The fraction of boards whose directors are mostly independent rises with time, as does the fraction whose independent directors are powerful. An increasing fraction of firms also separate the CEO and chair jobs and name a powerful director as chair. The importance of powerful independent directors on board committees also rises steadily through time. These are genuine changes in the data, not artifacts of the social network growing denser, because each individual's positions in the cross-sectional distributions of the power centralities in year $t$ to assess her power that year.

\subsection{Financial and Governance Data}

We use financial data from Compustat and stock return data from CRSP for our sample of S\&P 1500 firms from 1999 to 2010. Data for directors on S\&P 1500 firms' boards from ExecuComp and Risk Metrics include her age, assignments to audit, nominating and compensation committees, and compensation. We 
require firms to have at least three years of financial data. Merging with the board power measures above generates our 15,889 firm-year panel spanning 1,956 firms.

We measure shareholder valuation by Tobin's $Q$, book value of total assets plus market value of common shares minus book value of equity and deferred taxes, all divided by book value of total assets. We denote this $\mathrm{Q}_{h, t}$.

Our main regressions include control variables linked elsewhere to Q ratios: size (log of total assets); leverage (total debt over total assets), profitability (net operating cash flow plus depreciation and amortization over total assets); growth (net capital expenditure over net property, plant and equipment), intangibles (advertising and $R \& D$ expenditure, both scaled by total assets and set to zero if unreported), and industry fixed-effects. We also control for corporate governance variables linked elsewhere to Q ratios: the logs of CEO age (Yim 2013) and board size (Yermack 1996), as well as the Bebchuk, Cohen, and Farrell (2009) e-index, a composite index of management entrenchment devices. Explanatory variables are lagged one year in the regressions.

Tobin's Q in our sample of S\&P 1500 firms has a mean of 1.58 and a standard deviation of 1.55. The average board has nine directors. Independent directors are a majority in $91 \%$ of firm-year observations, but a majority of these are powerful in only $52 \%$. Summary statistics of the other variables accord other studies. Appendix Table A2 provides details.

\section{Empirical Results}

We hypothesize a predominance of powerful independent directors elevates shareholder value. In exploring this hypothesis, we also consider the presence of a powerful CEO, and a powerful non-CEO chair. This section presents our main empirical findings. Section 5 discusses robustness, with details in the Appendix.

\subsection{Board Power Structure and Shareholder Valuation}

Table 4 summarizes OLS explaining shareholder valuations with board independence. All regressions lag explanatory variables by one period, cluster by firm, include industry and year fixed-effects, and the control variables above. The last attract typical coefficients and significance levels. Larger firms, larger boards, more levered firms, and firms with more entrenched managers (higher e-index) tend to have lower Qs. Firms with higher investment, R\&D spending, and profitability tend to have higher Qs.

Our baseline result, regression 4.1, shows firms with powerful independent boards (PIB dummy $=1)$ have a $4.2 \%$ ( 0.0658 over the mean $\mathrm{Q}$ of 1.58$)$ valuation premium over other firms. Regression 4.2 , using the continuous independent director power measure IDC, likewise associates more powerful independent directors with higher shareholder valuations. Subsequent tables report only regressions using the $P I B$ dummy because $I D C$ perfectly mimics its sign and significance.

Regressions 4.3 through 4.6 show that powerful CEOs and powerful non-CEO chairs, represented 
by either a dummies for high power or a continuous power measure, are not significantly associated with higher valuations. Regressions 4.7 and 4.8 show that the association of independent director power is little affected by including CEO power and non-CEO chair power.

Table 5 summarizes the stark contrast between our independent direct power measures and conventional measure of director independence in additional regressions of the form of those in Table 4. Regressions 5.1 through 5.4 reveal conventional measures thought to enhance board effectiveness - more independent directors and the CEO not chairing the board - are statistically unrelated to higher shareholder valuations. The fraction of directors designated independent in proxy statements, FID, is associated with significantly depressed valuations. A majority of directors designated independent in disclosure statements is unrelated to valuation, as is and a two-thrids supermajority being so designated. A dummy for the CEO not chairing the board is likewise insignificant. In contrast, the powerful independent board dummy PIB is uniformly highly statistically and economically significant. Regression 5.7 reruns the baseline regrssion 4.1 including these conventional variables to. The point estimate on PID rises to about. 0.10 , implying a $6.5 \%$ permium ( 0.103 over the mean $Q$ of 1.58). Regressions 5.7 shows that this increase is largely due to controlling for the fraction of directors designated legally independent. These regressions affirm that powerful independent boards are associated with elevated valuations and that legally independent boards are not, nor are boards not chaired by the CEO.

\subsection{Identification via Powerful Independent Director Sudden Deaths}

The panel regressions in Tables 4 and 5 are consistent with powerful independent boards elevating shareholder valuations (direct causality). However, high valuations might also help firms attract and retain powerful directors (reverse causality), or other factors might both elevate shareholder valuations and draw powerful directors (latent factor causality), though controls proxying for plausible latent factors mitigate the latter problem.

To distinguish direct from reverse causality, we follow Nguyen and Nielsen (2010) in examining stock price reactions to directors' sudden deaths. LexisNexis and Google searches flag directors in our sample who die in office, and date these deaths. We exclude deaths coincident with confounding events, such as earnings or M\&A announcements, or the 9-11 attacks; as well as deaths after long illnesses. We define decedent directors as independent or not, and as powerful or not, as above. Cumulative abnormal returns (CARs) are daily total returns minus market model estimates, the parameters estimated using data for pre-event days -200 through -46 . This exercise is repeated using value- and equal-weighted CRSP total market returns.

Figure 2 summarizes the event study results, defining abnormal returns as stock returns minus the CRSP equal-weighted index return. Firms' stock prices drop significantly and substantially on news of a powerful independent director's sudden death. In contrast, cumulative abnormal returns (CARs) are 
insignificant on news of other independent directors' sudden deaths and positive on powerful nonindependent directors' sudden deaths.

Panel A of Table 6 quanitifies the patterns in Figure 2. Stock prices drop significantly, by $0.286 \%$ $(p=0.08)$, in the three-day $[-1,+1]$ window around sudden deaths of powerful independent directors; but rise significantly, by $1.65 \%(p=0.02)$, in the same window aroud sudden deaths of powerful nonindependent directors. Sudden deaths of non-powerful independent directors see stocks rise by a marginally signnificant $0.416 \%$ (one-tailed $p=0.09$ ) in the $[-1,+1]$ window, which excedes the price change around powerful indepdnend director sudden deaths by $0.702 \%(p=0.10)$. Similar patterns are evident in the longer windows, though several point estimates alternate between statistical significance $(p<0.10)$ and marginal (one-tailed) statistical significance $(p / 2<0.10)$.

These results suggest that Nguyen and Nielsen's (2010) findings associating independent director sudden deaths with stock price drops are primarily driven by to the sudden deaths of powerful independent directors. Sudden deaths of independent directors with low power move prices little. Powerful nonindependent directors' sudden deaths, in stark contrast, significantly boost shared prices.

Each column of Panel B summarizes a regression explaining stock price reactions to director sudden deaths with indicators for the decedent director being powerful (PD), independent (ID), and both powerful and independent (PID) along with the fixed effects and control variables used in Tables 4 and 5. The large and consistently significantly negative PID coefficients associate the sudden deaths of directors who are both powerful and independent with immediate downward pressure on stock prices after controlling for other director characteristics and firm characteristics.

The Tables 5 and Table 6 effects are economically significant and robust. ${ }^{8}$ The sudden death of a powerful independent director triggering a $2 \%$ share price drop implies a shareholder value loss of over $\$ 200$ million, given the mean market capitalization of $\$ 11.64$ billion in the relevant firms.

Finally, we note that the event study CARs gauge the value shareholders attach to powerful independent directors relative to likely replacements. Thus, normal returns might occur on powerful independent director deaths if shareholders expect equally powerful independent replacements. Succession studies reveal regressions to the mean in CEO ability (Brown 1982; Harrison \& Bazerman, 1995), and shareholders might expect something analogous in director power. That is, unusually powerful directors would be replaced by directors of more average power. To explore this, we use Boardex director announcement data to identify the directors who replaced a random sample of 49 (40 independent and 9

8 These results are highly robust. Checks include controlling for other director characteristics (Appendix Section A3), Granger causality tests (Appendix section A4), and dropping old director (age $>75$ and $>70$ ) deaths or including (possibly endogenous) suicides in the event studies (Appendix section A5). See section 5 and the Appendix for details, tables, and additional tests. 
nonindependent) directors who suddenly died. A clear regression to the mean is evident. Powerful independent director's replacements are more powerful than average, but significantly less powerful than the deceased directors they replace. ${ }^{9}$ Replacements are also significantly younger (mean age 55 at appointment) than the deceased directors (mean age 69 at death). Thus, shareholders might well expect very powerful independent directors' replacements to be more powerful than average, but less powerful than the decedents. If so, the CARs in Table 6 usefully predict the sign of the valuation shareholders attach to powerful independent directors, but may understate its magnitude.

\subsection{How Powerful Independent Directors Matter}

This section associates higher firm valuations with powerful independent directors curtailing valuedestroying M\&A, replacing underperforming CEOs, limiting free cash flow agency problems and limiting earnings management. ${ }^{10}$

\section{$M \& A$}

Mergers and acquisitions (M\&A) decisions are often a CEO's most momentous decisions. Valuedestroying M\&A bids are common and boards are blamed for not blocking M\&A bids pushed by misguided or utility maximizing CEOs (Moeller et al. 2004, 2005). Powerful independent directors might elevate valuations by blocking such value-destroying M\&A bids.

To explore this, we merge our data with Securities Data Company (SDC) M\&A data. This yeilds 632 M\&A bids for listed firms by 379 S\&P 1500 firms from 2000 through 2009. Bidder and combined (target and bidder) cumulative abnormal returns, denoted CAR $[-3,3]$, are measured from three days prior through three days after bid announcement dates. We drop acquirers with pre-acquisition majority ownership or post-acquisition ownership below $100 \%$ to remove stalled takeovers.

Table 7 regressions 7A.1 and 7A.2 show bidder CARs and bidder and target weighted-average CARs, respectively, on merger announcements to be higher if the bidder has a powerful independent board. The regressions control for other factors found important in this setting. CEO age (Jenter and Lewellen 2015), bidder size (Moeller et al. 2004, 2005), E-index entrenchment (Bebchuk et al. 2009), target and bidder in the same industry (Morck et al. 1990) and stock-financed bids (Myers and Majluf 1984), as well as year and bidder industry fixed-effects. Deal value is the cost of buying the target over the bidder's market capitalization in 7A.1, which explains bidder CARs, and the cost of buying the target over the combined market capitalization of the bidder and target in 7A.2, which explains the combined CARs. Finally, because El-Khatib, Fogel, and Jandik (2015) find firms with better-connected CEOs more prone to launch valuedestroying M\&A bids, 7A.1 and 7A.2 include the PCEO dummy, which flags powerful CEOs. The controls

9 We are grateful to Nagpurnanand Prabhala and Michael Weisbach for suggesting these tests.

10 Section 5 and Appendix section A7 show these findings highly robust. 
attract coefficients consistent with prior studies. In particular, the CEO power is significantly negative, with point estimates consistent with El-Khatib et al. (2015).

A powerful independent board correlates with a bidder CAR higher by $1.6 \%$ and a combined CAR higher by $1.5 \%$. Aggregating this across all deals in our sample implies an economically significant addition of almost $\$ 500$ million to shareholder wealth. These results contrast with Byrd and Hickman (1992), who link board independence to low bidder abnormal returns. Our results are consistent with powerful independent boards boosting shareholder valuations by deterring value-decreasing M\&A.

\section{Forced CEO turnover}

Weisbach (1988) links poor past firm performance with higher odds of forced CEO exit in firms with more independent boards. ${ }^{11}$ We follow Vancil (1987), who argues that boards choose new CEOs from the outgoing CEO's team of top managers unless they want to force a change in direction, in which case they slect an outsider. To exclude normal CEO retirements, we follow Morck et al. (1990) in using a subsample with departing CEOs aged 60 or younger. We flag as forced CEO turnovers as firm-year observations in which a successor from outside the firm replaces a CEO aged 60 or younger.

Regressions 7A.3 and 7A.4 associate powerful independent boards and powerful independent nominating committees, respectively, with higher odds forced CEO turnover after poor performance. The regresions are probits explaining a forced CEO turnover dummy with the firm's total stock return the prior year, $R E T$, an independent director power dummy for a powerful independent board $(P I B=1)$ in $7 \mathrm{~A} .3$ or for a powerful independent nominating committee $(P I B N=1)$ in $7 \mathrm{~A} .4$, and an interaction term. Weisbach (1988) shows an interaction of the prior return, RET, with an independent director measure, assesses the board's propensity to effect a forced CEO turnover. The interactions attract significantly negative coefficients in both regressions, consistent with powerful independent boards and powerful independent nominating committees being more apt to respond to more negative performance with forced CEO turnover.

Estimating the economic significance of an interaction in a probit requires comparing distributions of firm-year observation-level estimated changes in the conditional probability of abnormal turnover per unit change in the prior year's stock return with versus without a powerful independent board or nominating committee (Norton, Wang, and Ai 2004). The means of the implied interactions are $-18.3 \%$ and $-21.2 \%$ in 7A.3 and 7A.4, respectively; both statistically significant. Regtressions 7A.3 thus means a firm whose prior period return was $-50 \%$ versus $+50 \%$ return has an eighteen percentage points higher probability of a forced CEO turnover if it has a powerful independent board than if it does not. The equivalent difference in 7A.4 is a twenty-one percentage point higher probability of a forced CEO turnover with a powerful independent

11 See also Warner, Watts and Wruck (1988). These findings are extensively replicated and extended (e.g. Parrino 1997; Goyal and Park 2002; Hermalin and Weisbach 2003; Hazarika et al. 2012; Kaplan and Minton 2012). 
nominating committee versus without one. These results are consistent with powerful independent boards and nominating committees elevating shareholder value by being readier to oust underperforming CEOs.

\section{Free Cash Flow}

Jensen (1986) argues that ineffective boards let utility maximizing top managers retain earnings and use them unprofitably. High cash flow, low dividends, and low shareholder valuation can thus signal free cash flow agency problems (Lang and Litzenberger 1989; Lang, Stulz, and Walkling 1991; La Porta et al. 2000). Our proxy for a likely free cash flow problem is therefore an indicator variable set to one if the firm has a below-median Tobin's Q, an above-median cash flow to property, plant and equipment ratio, and a belowmedian payout ratio; and to zero otherwise.

Regressions 7B.1 and 7B.2 summarize probit regressions of the likely free cash flow problem dummy on the powerful independent board dummy. The control variables are consistent with prior work: lower leverage and greater managerial entrenchment correlate significantly with likely free cash flow problems. Regression 7B.2 also controls for CEO power, which enters insignificantly. Consistent with Jensen's argument, firms with powerful independent board are significantly less prone to free cash flow problems. The point estimates are economically significant: a powerful independent board corresponds to a $22 \%$ lower likelihood of a firm being designated as likely to suffer from free cash flow problems.

\section{Earnings Management}

Empirical evidence links more earnings manipulation to less effective internal controls (Doyle et al. 2007), less forced CEO turnover (DeAngelo 1988; Dechow \& Sloan 1991), and less independent boards and audit committees (Klein 2002). Earnings manipulation can be assessed by estimating abnomral accruals (Jones 1991) adjusting for credit and sales growth (Dechow et al. 1995) benchmarking with ROA-matched controls within industries each year (Kothari et al. 2005).

Regressions 7B.3 and 7B.4 explain abnormal earnings accruals with either the powerful independent board dummy, PIB, or a powerful independent auditing committeedummy, PIBA. Abnormal accruals are significantly lower in firms with powerful independent boards and marginally significantly lower $(\mathrm{p}=0.11)$ in firms with powerful independent audit committees. The point estimate in $7 \mathrm{~B} .3$ is economically significant, associating a powerful independent board with a 50\% $(-0.00402$ over mean abnormal accruals of 0.00819 ) cut in abnormal accruals. The other coefficients associate more earnings management with older CEOs, less powerful CEOs, lower capital investment, and higher earnings. These findings are consistent with powerful independent directors elevating shareholder valuations by limiting earnings management.

\section{CEO Compensation}

Finally, Bebchuk and Fried (2006) associate higher shareholder valuations with CEO being tied to 
shareholder value increases. Our thesis suggests powerful independent boards and powerful independent compensation committees might increase firm valuations by better linking CEO pay to past performance. Regressions (see Appendix Section A8) analogous to 7A.3 and 7A.4, show CEO pay (from BoardEx) to be significantly more equity-linked and significantly more sensitive to prior equity returns in firms with powerful independent boards or powerful independent compensation committee. These regressions control for CEO power, and not doing so obscures the above result. CEO power correlates significantly positively with CEO pay regardless of prior performance, consistent with powerful CEOs becoming entrenched (Fracassi and Tate, 2012; El-Khatib et al. 2015). Higher equity-linked CEO pay regardless of performance can occur that pay is timed or adjusted to counter adverse stock price fluctuations (Bebchuk et al. 2010). Powerful independent boards and powerful independent compensation committees are also associated with higher total CEO pay and higher cash CEO pay, perhaps as compensation for less quiet lives (Bertrand and Mullainathan 2003). Overall, additional tests using CEO pay reaffirm our main conclusion by associating powerful independent directors with CEOs being paid to focus on shareholder value.

\section{Robustness Checks}

The results in the tables pass a battery of robustness checks, including alternative ways of defining the power measures, alternative estimation approaches, alternative ways of constructing key variables, alternative event study methodologies, and using Granger causality tests to infer causality. In almost all cases, the robustness checks generate qualitatively similar results, meaning the powerful independent director measures' coefficients have patterns of signs and significance identical to the tables and magnitudes consistent with the tables. The Appendix explains the full array of robustness checks, tabulates key results, and reconciles the isolated qualitatively different results with the general conclusions of this paper in the context of other work. This section presents robustness check that may reveal additional insights.

One such set of robustness checks reveals connections to other studies that associate director characteristics to Q ratios. Including a dummy for an intensive monitoring board, which Faleye et al. (2011) define as having a majority of independent directors on at least two of its three main monitoring committees, does not qualitatively change the results. Nor does including a dummy for a busy board, which Fich and Shivdasani (2006) define as a board in which a majority of independent directors serve on three or more other boards. Including independent director experience, defined as in Kang (2013) as the independent directors' mean years of experience on boards of publicly-traded firms, also leaves our results qualitatively unchanged. Controlling for high independent director share ownership (Bhagat and Bolton 2013) also generates results qualitatively similar to the tables. Controlling for the experience or share ownership of all directors, rather than just independent directors, likewise leaves the results qualitatively unchanged. These results suggest independent director power has traction over and above these other 
director characteristics.

Another set of robustness checks shows nonindependent director power measures attaining significance in some tests; however further investigation suggests reverse causality so we are reluctant to stress these findings. Table 5 shows Q unrelated to the CEO chairing the board and analogous regressions show Q unrelated to a powerful independent director as chair. However, $q$ is higher if a powerful nonindependent director is chair, a majority of nonindependent directors are powerful, or average nonindependent director power is higher. Controlling for these variables generates results qualitatively similar to the tables; however, the positive relationship between $\mathrm{Q}$ and nonindependent director power in these robustness checks seems at odds with the event studies, in which powerful independent director sudden deaths increase valuations. Granger causality tests (Appendix Table A5), an alternative approach to assessing causality developed for time series and adapted for panel data (Hurlin 2005; Dumitrescu and Hurlin 2012; Lopez and Weber. 2017; Elliott, and Golub 2019) suggest unidirectional causality from independent director power ( $P I B$ or $I D C$ ) to $Q$ and from $\mathrm{Q}$ to nonindependent director and nonindependent chair power. A high valuation thus attracts powerful nonindependent director, whose sudden deaths can further increase valuation. In contrast, powerful independent directors and boards boost valuations, so share prices drop on their sudden deaths.

Finally, the Sarbanes-Oxley (SOX) reforms were implemented in 2003, in the middle of the time window we study. This allows tests of SOX reforms as a possible institutional break-point. ${ }^{12}$ Post-SOX data yield results qualitatively similar to those in the tables. In contrast, the pre-SOX data generates insignificant coefficients in Table 4, though Table 5 is preserved. As a further robustness check, we reestimate Table 4 on a cross-section of data for each year from 2000 through 2010. The coefficients on PID and $I D C$ are always positive, but attain significance only intermittently - PID in 2007, 2009 and 2010 and $I D C$ in 2001, 2003, 2005, 2007 and 2010. We are reluctant to stress these insignificant results because smaller samples in the cross-sections and pre-SOX tests may induce attenuate bias.

\section{Conclusions and Implications}

We conclude that powerful independent directors elevate shareholder valuations; and do so, in part at least, by deterring value-destroying decisions such as unsound merger bids, excessive free cash flow retention, problematic CEO retention, aggressive earnings manipulation, and CEO pay unrelated to performance. Independent directors who are not powerful appear unwilling or unable to do these things.

The high incidence of powerless independent directors in the data is consistent with many CEOs selecting independent directors for diffidence (Mace 1986; Hwang and Kim 2009). Post mortems of corporate governance shipwrecks suggest describe corporate cultures that equated dissent with disloyalty.

\footnotetext{
${ }^{12}$ We are grateful to Nagpurnanand Prabhala for suggesting these tests.
} 
For example, an Enron executive describes an "atmosphere of intimidation" in which many worried about the firm, but none dared confront the CEO (Cohan 2002). We suggest a behavioral interpretation of director subservience to CEOs. Obedience to authority is a readily triggered human response (Milgram 1975) and may be a form of decision making Kahneman (2011) calls thinking fast, as opposed to thinking slow - the rational decision making of economic theory. Kahneman argues that economic and natural selection favors thinking fast if the costs of errors this causes do not exceed the cost of information gathering and processing thinking slow requires. Consequently, humans default to thinking fast and only activate thinking slow if thinking fast fails to converge. Obedience to authority fails to converge if two authorities conflict. We posit that the presence of sufficiently powerful independent directors in sufficient numbers on corporate boards can interrupt reflexive obedience to a CEO and activate rational deliberation.

Obviously, boards cannot be debating societies. CEOs selected for expertise necessarily know things others do not, and excessively critical boards could unduly curtail trailblazing CEOs (Adams et al. 2005). Our findings suggest that reforms to director nomination and selection processes might be evaluated, in part at least, for efficacy in fostering loyal opposition by screening out "yes men" while protecting legitimate CEO discretion.

Our data are from 1999 to 2010, when good corporate governance was associated with high shareholder valuations (Gompers et al. 2003; Kaplan and Minton 2012; Bebchuk et al. 2013). In the 2010s, good corporate governance increasingly became associated with balancing the interests of stakeholders employees, creditors, customers, suppliers, the environment, the community, society, and others. This redefinition reflects concerns that CEOs and boards might boost share prices by price-fixing or lobbying for government favors. This leaves Q ratios a less defensible measure of good governance and our methodology consequently less useful. Nonetheless, extrapolating that boards with powerful independent directors capable of credibly challenging an errant CEO would better attain corporate objectives, however defined, seems defensible

Finally, our results have implications for business ethics regarding corporate boards. Hirschman (1970) explains that people, confronted with unethical or inept behavior in an organization, have three response options: exit, voice, and loyalty. A problematic CEO leaves non-powerful independent directors only two choices: exit (resignation) or loyalty (becoming a "yes man"). As Milgram (1975) discusses at length, an agentic shift, deontological (duty-focused) ethics displacing teleological (outcomes-focused) ethics, favors the "loyalty" option. Loyal directors can view themselves as highly ethical even as their CEO leads the firm towards disaster. Business ethics might consider how and when public policy might encourage deontological versus teleological ethical reasoning in corporate governance. 


\section{References}

Adams, RB, Almeida, H \& Ferreira, D. (2005). Powerful CEOs \& Their Impact on Corporate Performance. Review of Financial Studies, 18(4)1403-1432. https://doi.org/10.1093/rfs/hhi030

Adams, RB, Hermalin, BE \& Weisbach, MS (2010). The Role of Boards of Directors in Corporate Governance: A Conceptual Framework \& Survey. Journal of Economic Literature, 48(1)58-107. https://doi.org/10.1257/jel.48.1.58

Adams, RB. 2017. Boards, and the directors who sit on them. In M. Weisbach and B Hermalin, eds. Handbook of the Economics of Corporate Governance. North-Holland, 291-382.

Ahern, KR \& Dittmar, AK. (2012) The changing of the boards: The impact on firm valuation of mandated female board representation. Quarterly Journal of Economics 127(1)137-197.

Baldwin, M. (2017). In referees we trust. Physics Today 70(2)44-49.

Banerjee, A, Chandrasekhar, AG, Duflo, E \& Jackson, MO. (2013). The Diffusion of Microfinance. Science, 341(6144), 1236498. https://doi.org/10.1126/science.1236498

Baumeister, RE. Bratslavsky, Muraven, M \& Tice, D. 1998. Ego Depletion: Is the Active Self a Limited Resource? Journal of Personality and Social Psychology 74(5)1252-65.

Bebchuk, LA \& Fried, J. M. (2006). Pay without performance: The unfulfilled promise of executive compensation. Harvard University Press.

Bebchuk, LA, Cohen, A \& Ferrell, A. (2009). What Matters in Corporate Governance? Review of Financial Studies, 22(2)783-827. https://doi.org/10.1093/rfs/hhn099

Bebchuk, LA, Cohen, A \& Wang, CCY (2013). Learning \& the disappearing association between governance \& returns. Journal of Financial Economics, 108(2)323-348. https://doi.org/10.1016/j.jfineco.2012.10.004

Bebchuk, LA, Grinstein, Y \& Peyer, U. 2010. Lucky CEOs \& lucky directors. Journal of Finance 65(6)2363-401.

Bernardo, A E. \& Welch, I. (2001). On the Evolution of Overconfidence \& Entrepreneurs. Journal of Economics \& Management Strategy, 10(3), 301-330. https://doi.org/10.1162/105864001316907964

Bertrand, M, \& Mullainathan, S. 2003. Enjoying the quiet life? Corporate governance \& managerial preferences. Journal of Political Economy 111(5)1043-75.

Bhagat, S \& Bolton, B. (2013). Director Ownership, Governance \& Performance. Journal of Financial \& Quantitative Analysis, 48(1), 105-135. https://doi.org/10.1017/S0022109013000045

Bikhchandani, S, Hirshleifer, D \& Welch, I. (1992). A Theory of Fads, Fashion, Custom \& Cultural Change as Informational Cascades. Journal of Political Economy, 100(5), 992-1026. https://doi.org/10.1086/261849

Black, B, Cheffins, B \& Klausner, M. (2006). Outside Director Liability. Stanford Law Review, 58(4), 1055-1159.

Blass, T. (2004). The Man Who Shocked the World: The Life \& Legacy of Stanley Milgram. BMJ, 331(7530), 1481-1481. https://doi.org/10.1136/bmj.331.7530.1481-a

Blass, T. (2012). A Cross-Cultural Comparison of Studies of Obedience Using the Milgram Paradigm: A Review. Social \& Personality Psychology Compass 6(2)196-205. https://doi.org/10.1111/j.1751-9004.2011.00417.x

Bolland, JM. (1988). Sorting out centrality: An analysis of the performance of four centrality models in real \& simulated networks. Social Networks, 10(3), 233-253. https://doi.org/10.1016/0378-8733(88)90014-7

Bonacich, P. (1972). Factoring \& weighting approaches to status scores \& clique identification. Journal of Mathematical Sociology, 2(1), 113-120. https://doi.org/10.1080/0022250X.1972.9989806

Borgatti, SP, Carley, KM \& Krackhardt, D. (2006). On the robustness of centrality measures under conditions of imperfect data. Social Networks, 28(2), 124-136. https://doi.org/10.1016/j.socnet.2005.05.001

Borgatti, SP. (2006). Identifying sets of key players in a social network. Computational \& Mathematical Organization Theory 12(1)21-34. https://doi.org/10.1007/s10588-006-7084-x

Bregman, R. (2020). Humankind: A hopeful history. Bloomsbury 
Brochet, F \& Srinivasan, S. (2014). Accountability of independent directors: Evidence from firms subject to securities litigation. Journal of Financial Economics 111(2)430-49. doi.org/10.1016/j.jfineco.2013.10.013

Brown, MC. (1982). Administrative Succession \& Organizational Performance: The Succession Effect. Administrative Science Quarterly, 27(1), 1-16. https://doi.org/10.2307/2392543

Burger, JM. (2009). Replicating Milgram: Would People Still Obey Today? American Psychologist 64(1)1-11. https://doi.org/10.1037/a0010932

Burt, R. (2009). Structural holes: The social structure of competition. Harvard University Press.

Byrd, JW. \& Hickman, KA. (1992). Do outside directors monitor managers?: Evidence from tender offer bids. Journal of Financial Economics, 32(2), 195-221. https://doi.org/10.1016/0304-405X(92)90018-S

Caspar, EA, Bue, SL, Haggard, P \& Cleeremans. A. (2020a) The effect of military training on the sense of agency \& outcome processing. Nature Communications 11(1),1-10.

Caspar, EA, Ioumpa, K, Keysers, C \& Gazzola V. (2020) Obeying orders reduces vicarious brain activation towards victims' pain. NeuroImage 222 (1)17251.

Chidambaran, NK, Kedia, S \& Prabhala, NR. (2012). CEO-Director Connections \& Corporate Fraud. SSRN Electronic Journal. https://doi.org/10.2139/ssrn.2023030

Cohan, JA. (2002). “I Didn’t Know” \& “I Was Only Doing My Job”: Has Corporate Governance Careened out of Control? A Case Study of Enron's Information Myopia. Journal of Business Ethics, 40(3), 275-299. https://doi.org/10.1023/A:1020506501398

Coles, JL, Daniel, ND \& Naveen, L. (2014). Co-opted Boards. Review of Financial Studies, 27(6), 1751-1796. https://doi.org/10.1093/rfs/hhu011

Costenbader, E \& Valente, TW. (2003). The stability of centrality measures when networks are sampled. Social Networks, 25(4), 283-307. https://doi.org/10.1016/s0378-8733(03)00012-1

Costenbader, E \& Valente, TW. (2004). Corrigendum to "The stability of centrality measures when networks are sampled" [Social Networks 25 (2003) 283-307]. Social Networks, 26(4), 351-351. https://doi.org/10.1016/j.socnet.2004.08.002

Dambrun, M \& Vatiné, E. (2010). Reopening the study of extreme social behaviors: Obedience to authority within an immersive video environment. European Journal of Social Psychology 40(5)760-773.

Deacon, RT. (2009). Public good provision under dictatorship and democracy. Public Choice, 139(1), 241-262.

DeAngelo, LE. (1988). Managerial competition, information costs \& corporate governance: The use of accounting performance measures in proxy contests. Journal of Accounting \& Economics, 10(1), 3-36. https://doi.org/10.1016/0165-4101(88)90021-3

Dechow, PM \& Sloan, RG. (1991). Executive incentives \& the horizon problem: An empirical investigation. Journal of Accounting \& Economics 14(1)51-89. https://doi.org/10.1016/0167-7187(91)90058-S

Dechow, PM, Sloan, RG \& Sweeney, AP. (1995). Detecting Earnings Management. Accounting Review 70(2)93-25.

Demsetz, H \& Lehn K. (1985) .The structure of corporate ownership: Causes and consequences. Journal of Political Economy 93.6 1155-77.

Doliński, D, Grzyb, T, Folwarczny, M, Grzybała, P, Krzyszycha, K, Martynowska, K \& Trojanowski, J. (2017). Would you deliver an electric shock in 2015? Obedience in the experimental paradigm developed by Stanley Milgram in the 50 years following the original studies. Social Psychological \& Personality Science, 8(8)927-933.

Doyle, JT, Ge, W \& McVay, S. (2007). Accruals Quality \& Internal Control over Financial Reporting. Accounting Review, 82(5)1141-1170. https://doi.org/10.2308/accr.2007.82.5.1141

Dumitrescu, EI \& Hurlin, C. 2012. Testing for Granger non-causality in heterogeneous panels. Economic Modelling 29: $1450-1460$

El-Khatib, R, Fogel, K \& Jandik, T. (2015). CEO network centrality \& merger performance. Journal of Financial 
Economics, 116(2), 349-382. https://doi.org/10.1016/j.jfineco.2015.01.001

Elliott, M \& Golub, B (2019). A Network Approach to Public Goods. Journal of Political Economy 127(2)730-76. doi:10.1086/701032. ISSN 0022-3808.

Engelberg, J, Gao, P \& Parsons, C. A. (2013). The Price of a CEO's Rolodex. The Review of Financial Studies, 26(1), 79-114. https://doi.org/10.1093/rfs/hhs114

Faleye, O, Hoitash, R \& Hoitash, U. (2011). The costs of intense board monitoring. Journal of Financial Economics, 101(1), 160-181. https://doi.org/10.1016/j.jfineco.2011.02.010

Faleye, O. (2009). Classified Boards, Stability \& Strategic Risk Taking. Financial Analysts Journal, 65(1), 54-65. https://doi.org/10.2469/faj.v65.n1.9

Fama, EF. (1980). Agency Problems \& the Theory of the Firm. The Journal of Political Economy, 88(2), 288-307. https://doi.org/10.1086/260866

Ferris, SP, Jagannathan, M \& Pritchard, AC. (2003). Too Busy to Mind the Business? Monitoring by Directors with Multiple Board Appointments. The Journal of Finance (New York), 58(3), 1087-1111. https://doi.org/10.1111/1540-6261.00559

Ferris, SP, Kim, KA, Nishikawa, T \& Unlu, E. (2011) Reaching for the stars: the appointment of celebrities to corporate boards. International Review of Economics 58(4)337-358.

Fich, EM \& Shivdasani, A. 2006. Are Busy Boards Effective Monitors? Journal of Finance 61(2)689-724.

Fich, EM \& Shivdasani, A. 2007. Financial fraud, director reputation, and shareholder wealth. Journal of Financial Economics 86(2)306-336.

Fos, V \& Tsoutsoura, M. (2014). Shareholder democracy in play: Career consequences of proxy contests. Journal of Financial Economics, 114(2), 316-340. https://doi.org/10.1016/j.jfineco.2014.07.009

Fracassi, C \& Tate, G. (2012). External Networking \& Internal Firm Governance. Journal of Finance (New York), 67(1), 153-194. https://doi.org/10.1111/j.1540-6261.2011.01706.x

Freeman, LC, Roeder, D \& Mulholland, RR. (1979). Centrality in social networks: II. Experimental results. Social Networks, 2(2), 119-141. https://doi.org/10.1016/0378-8733(79)90002-9

Freeman, LC. (1977). A Set of Measures of Centrality Based on Betweenness. Sociometry, 40(1), 35-41. https://doi.org/10.2307/3033543

Freeman, LC. (1978). Centrality in social networks conceptual clarification. Social Networks, 1(3), 215-239. https://doi.org/10.1016/0378-8733(78)90021-7

Gompers, P, Ishii, J \& Metrick, A. (2003). Corporate Governance \& Equity Prices. The Quarterly Journal of Economics, 118(1), 107-156. https://doi.org/10.1162/00335530360535162

Goyal, VK \& Park, CW. (2002). Board leadership structure \& CEO turnover. Journal of Corporate Finance 8(1)4966. https://doi.org/10.1016/s0929-1199(01)00028-1

Hanneman, RA \& Riddle, M. (2005). Introduction to Social Network Methods. University of California, Riverside. CA. http://faculty.ucr.edu/ hanneman

Harrison, RJ \& Bazerman, MH. (1995). Regression to the Mean, Expectation Inflation \& the Winner's Curse in Organizational Contexts. In R. Kramer \& D. Messick, Negotiation as a Social Process (pp. 69-94). SAGE Publications, Inc. https://doi.org/10.4135/9781483345369.n4

Hauser, R. (2018). Busy directors \& firm performance: Evidence from mergers. Journal of Financial Economics, 128(1), 16-37.

Hazarika, S, Karpoff, JM \& Nahata, R. (2012). Internal corporate governance, CEO turnover \& earnings management. Journal of Financial Economics, 104(1), 44-69. https://doi.org/10.1016/j.jfineco.2011.10.011

Hermalin, BE \& Weisbach, MS. (1998). Endogenously Chosen Boards of Directors \& Their Monitoring of the CEO. The American Economic Review, 88(1), 96-118. 
Hermalin, BE \& Weisbach, MS. (2003). Board of directors as an endogenously determined institution: A survey of the economic literature. (Part 1: A review of the literature on corporate governance). Economic Policy Review (Federal Reserve Bank of New York), 9(1), 7.

Higgs, D. (2003). Review of the role \& effectiveness of non-executive directors. www.bis.gov.uk/files/file23012.pdf

Hirsch, J, Tiede, M, Zhang, X, Noah, J. A, Manteau, A \& Biriotti, M. (2021). The Neurobiology of Interpersonal Agreement \& Disagreement during Face-to-Face Dialogue. Frontiers in Human Neuroscience, 14, 601. doi: $10.3389 /$ fnhum.2020.606397

Hirschman, AO. (1970). Exit, voice \& loyalty responses to decline in firms, organizations \& states. In Hirschman, AO, ed. Exit, Voice \& Loyalty. Harvard University Press.

Hossain, L, Chung, KSK \& Murshed, STH. (2007). Exploring Temporal Communication through Social Networks. 4662, 19-30. https://doi.org/10.1007/978-3-540-74796-3_5

Hurlin, C. 2005. Testing Granger causality in heterogeneous panel data models. Revue Economique 56.3 799-809.

Hwang, BH \& Kim, S. (2009). It pays to have friends. Journal of Financial Economics, 93(1), 138-158. https://doi.org/10.1016/j.jfineco.2008.07.005

Janis, IL. (1971). Groupthink. Psychology Today, 5, 43-46, 74-76.

Jensen, MC \& Meckling, WH. (1976). Theory of the firm: Managerial behavior, agency costs \& ownership structure. Journal of Financial Economics, 3(4), 305-360. https://doi.org/10.1016/0304-405X(76)90026-X

Jensen, MC. (1986). Agency Costs of Free Cash Flow, Corporate Finance \& Takeovers. The American Economic Review, 76(2), 323-329.

Jenter, D \& Lewellen, K. (2015). CEO Preferences \& Acquisitions. The Journal of Finance (New York), 70(6), 2813-2852. https://doi.org/10.1111/jofi.12283

Jones, J. J. (1991). Earnings Management during Import Relief Investigations. Journal of Accounting Research, 29(2), 193-228. https://doi.org/10.2307/2491047

Kahneman, D. (2011). Thinking, fast \& slow (1st ed.). Farrar, Straus \& Giroux.

Kang, S. (2013). Experienced Independent Directors. SSRN Electronic Journal. https://doi.org/10.2139/ssrn.2240650

Kaplan, S. N \& Minton, B. A. (2012). How Has CEO Turnover Changed? International Review of Finance, 12(1), 57-87. https://doi.org/10.1111/j.1468-2443.2011.01135.x

Kim, D \& Starks, LT. (2016) Gender diversity on corporate boards: Do women contribute unique skills? American Economic Review 106.5 267-71.

Kiss, C \& Bichler, M. (2008). Identification of influencers - Measuring influence in customer networks. Decision Support Systems, 46(1), 233-253. https://doi.org/10.1016/j.dss.2008.06.007

Klein, A. (2002). Audit committee, board of director characteristics \& earnings management. Journal of Accounting \& Economics, 33(3), 375-400. https://doi.org/10.1016/s0165-4101(02)00059-9

Kothari, SP, Leone, AJ \& Wasley, CE. (2005). Performance matched discretionary accrual measures. Journal of Accounting \& Economics, 39(1), 163-197. https://doi.org/10.1016/j.jacceco.2004.11.002

La Porta, R, Lopez-de-Silanes, F \& Shleifer A. (2013) Law and finance after a decade of research. Handbook of the Economics of Finance. Elsevier, pp. 425-491.

La Porta, R, Lopez-de-Silanes, F \& Shleifer, A(2008) The economic consequences of legal origins. Journal of Economic Literature 46(2)285-332.

La Porta, R, Lopez-de-Silanes, F, Shleifer, A \& Vishny, RW. (2000). Agency Problems \& Dividend Policies around the World. The Journal of Finance (New York), 55(1), 1-33. https://doi.org/10.1111/0022-1082.00199

Lang, LHP \& Litzenberger, RH. (1989). Dividend announcements. Journal of Financial Economics, 24(1)181-191. https://doi.org/10.1016/0304-405x(89)90077-9 
Lang, LHP, Stulz, R \& Walkling, RA. (1991). A test of the free cash flow hypothesis: The case of bidder returns. Journal of Financial Economics, 29(2), 315-335. https://doi.org/10.1016/0304-405X(91)90005-5

Lee, S. H, Cotte, J \& Noseworthy, TJ. (2010). The role of network centrality in the flow of consumer influence. Journal of Consumer Psychology, 20(1), 66-77. https://doi.org/10.1016/j.jcps.2009.10.001

Lopez, L \&Weber, S. 2017. Testing for Granger causality in panel data. Stata Journal 17(9)972-84.

Mace, M. L. (1986). Directors, myth \& reality (Rev. ed.). Harvard Business School Press.

Martin, J, Lobb, B, Chapman, GC \& Spillane, R. (1976). Obedience under Conditions Demanding Self-Immolation. Human Relations, 29(4), 345-356. https://doi.org/10.1177/001872677602900403

Masulis, RW \& Mobbs, S. (2014). Independent director incentives: Where do talented directors spend their limited time \& energy? Journal of Financial Economics 111(2)406-29.

Masulis, RW and Zhang E. (2019). How valuable are independent directors? Evidence from external distractions. Journal of Financial Economics 132 (3) 226-256,

Mermillod, M, Marchand, V, Lepage, J, Begue, L \& Dambrun, M. (2015). Destructive Obedience Without Pressure. Social Psychology 46(6)345-51.

Milgram, S. (1967). The small world problem. Psychology Today, 1(1), 61-67.

Milgram, S. (1975). Obedience to authority: An experimental view. Harper \& Row.

Milgram, S. 1963. Behavioral study of obedience. Journal of Abnormal \& Social Psychology. 67(4) 371-86.

Milgram, S. 1965. Some conditions of obedience and disobedience to authority. Human Relations 18(1) 57-76.

Miller, AG. (1986). The obedience experiments: A case study of controversy in social science. Praeger.

Miller, AG. (2016). Why are the Milgram Obedience Experiments still so extraordinarily famous-and controversial. In Miller, AG., ed. The social psychology of good and evil. Guilford, pp. 185-223. .

Moeller, SB, Schlingemann, FP \& Stulz, RM. (2004). Firm size \& the gains from acquisitions. Journal of Financial Economics, 73(2), 201-228. https://doi.org/10.1016/j.jfineco.2003.07.002

Moeller, SB, Schlingemann, FP \& Stulz, RM. (2005). Wealth Destruction on a Massive Scale? A Study of Acquiring-Firm Returns in the Recent Merger Wave. Journal of Finance 60(2), 757-782. https://doi.org/10.1111/j.1540-6261.2005.00745.x

Morck, R, Shleifer, A \& Vishny RW. (1989). Alternative Mechanisms for Corporate Control. American Economic Review 79(4)842-52

Morck, R, Shleifer, A \& Vishny, RW. (1990). Do Managerial Objectives Drive Bad Acquisitions? Journal of Finance 45(1), 31-48. https://doi.org/10.1111/j.1540-6261.1990.tb05079.x

Morck, R, Shleifer, S \& Vishny RW. (1988) Management ownership and market valuation: An empirical analysis. Journal of financial economics 20 (1988): 293-315. https://doi.org/10.1016/0304-405X(88)90048-7

Morck, R. (2008). Behavioral finance in corporate governance: Economics \& ethics of the devil's advocate. Journal of Management \& Governance, 12(2), 179-200. https://doi.org/10.1007/s10997-008-9059-4

Myers, SC \& Majluf, NS. (1984). Corporate financing \& investment decisions when firms have information that investors do not have. Journal of Financial Economics, 13(2), 187-221. https://doi.org/10.1016/0304$405 \times(84) 90023-0$

Nguyen, BD \& Nielsen, KM. (2010). The value of independent directors: Evidence from sudden deaths. Journal of Financial Economics, 98(3), 550-567. https://doi.org/10.1016/j.jfineco.2010.07.004

Norton, EC, Wang, H \& Ai, C. (2004). Computing Interaction Effects \& Standard Errors in Logit \& Probit Models. The Stata Journal, 4(2), 154-167. https://doi.org/10.1177/1536867X0400400206

Packer, DJ. (2008). Identifying Systematic Disobedience in Milgram's Obedience Experiments: A Meta-Analytic Review. Perspectives on Psychological Science, 3(4), 301-304. https://doi.org/10.1111/j.1745-

6924.2008.00080.x 
Padgett, JF \& Ansell, CK. (1993). Robust Action \& the Rise of the Medici, 1400-1434. The American Journal of Sociology, 98(6), 1259-1319. https://doi.org/10.1086/230190

Perry G. (2013). Behind the shock machine: The untold story of the notorious Milgram psychology experiments. New Press.

Pinker, S. (2012). The better angels of our nature: Why violence has declined. Penguin

Proctor, CH \& Loomis, CP. (1951). Analysis of sociometric data. Research Methods in Social Relations.

Romm, C. 2015. Rethinking One of Psychology's Most Infamous Experiments. The Atlantic, Jan 28.

Sabidussi, G. (1966). The centrality index of a graph. Psychometrika, 31(4), 581-603. https://doi.org/10.1007/bf02289527

Sheridan, CL \& King, RG. (1972). Obedience to authority with an authentic victim. Proceedings of the Annual Convention of the American Psychological Association, 7(Pt. 1), 165-166.

Simon, HA. 1997. Models of bounded rationality. MIT Press

Slater M, Antley A, Davison A, Swapp D, Guger C, Barker C, Pistrang N \& Sanchez-Vives MV. (2006). A virtual reprise of the Stanley Milgram obedience experiments. PloS1 1(11)e39 https://doi.org/10.1371/journal.pone.0000039

Srinivasan, S. (2005). Consequences of Financial Reporting Failure for Outside Directors: Evidence from Accounting Restatements \& Audit Committee Members. Journal of Accounting Research, 43(2), 291-334. https://doi.org/10.1111/j.1475-679x.2005.00172.x

Suen, VY, Brown, MR, Morck, R, \& Silverstone, PH. 2014. Regional brain changes occurring during disobedience to "Experts" in financial decision-making. PloS one, 9(1)e87321. doi: 10.1371/journal.pone.0087321

Vancil, RF. (1987). Passing the baton: Managing the process of CEO succession. Harvard Business School Press.

Watts, DJ \& Dodds PS. (2007) Influentials, networks \& public opinion formation. Journal of Consumer Research $34.4441-458$

Watts, DJ \& Strogatz, SH. (1998). Collective dynamics of 'small-world' networks. Nature (London), 393(6684), 440-442. https://doi.org/10.1038/30918

Weisbach, MS. (1988). Outside directors \& CEO turnover. Journal of Financial Economics, 20(1), 431-460. https://doi.org/10.1016/0304-405x(88)90053-0

Wilson, EO. 2012. The Social Conquest of Earth. Liveright.

Yermack, D. (1996). Higher market valuation of companies with a small board of directors. Journal of Financial Economics 40(2)185-211. https://doi.org/10.1016/0304-405x(95)00844-5

Yim, S. (2013) The acquisitiveness of youth: CEO age \& acquisition behavior. Journal of Financial Economics 108(1)250-73. http://dx.doi.org/10.1016/j.jfineco.2012.11.003 


\section{Figure 1. Baseline Obedience and the Disruption of Obedience}

This figure summarizes baseline results of Milgram's (1975) obedience experiments, in which subjects applied increasing electric shocks to an actor feigning increasing pain as ordered by Milgram (solid line). A second psychologist entering after the 150 volt level is reached, criticizing the proceedings, and leaving caused obedience to cease entirely (dashed line). A second subject, observing the experiment, voicing criticism reduced obedience to a lesser extent (dotted line). This is consistent with an obedience to authority heuristic failing to converge if two comparably credible authority figures disagree, and this activating rational decision making as in Kahneman (2011).

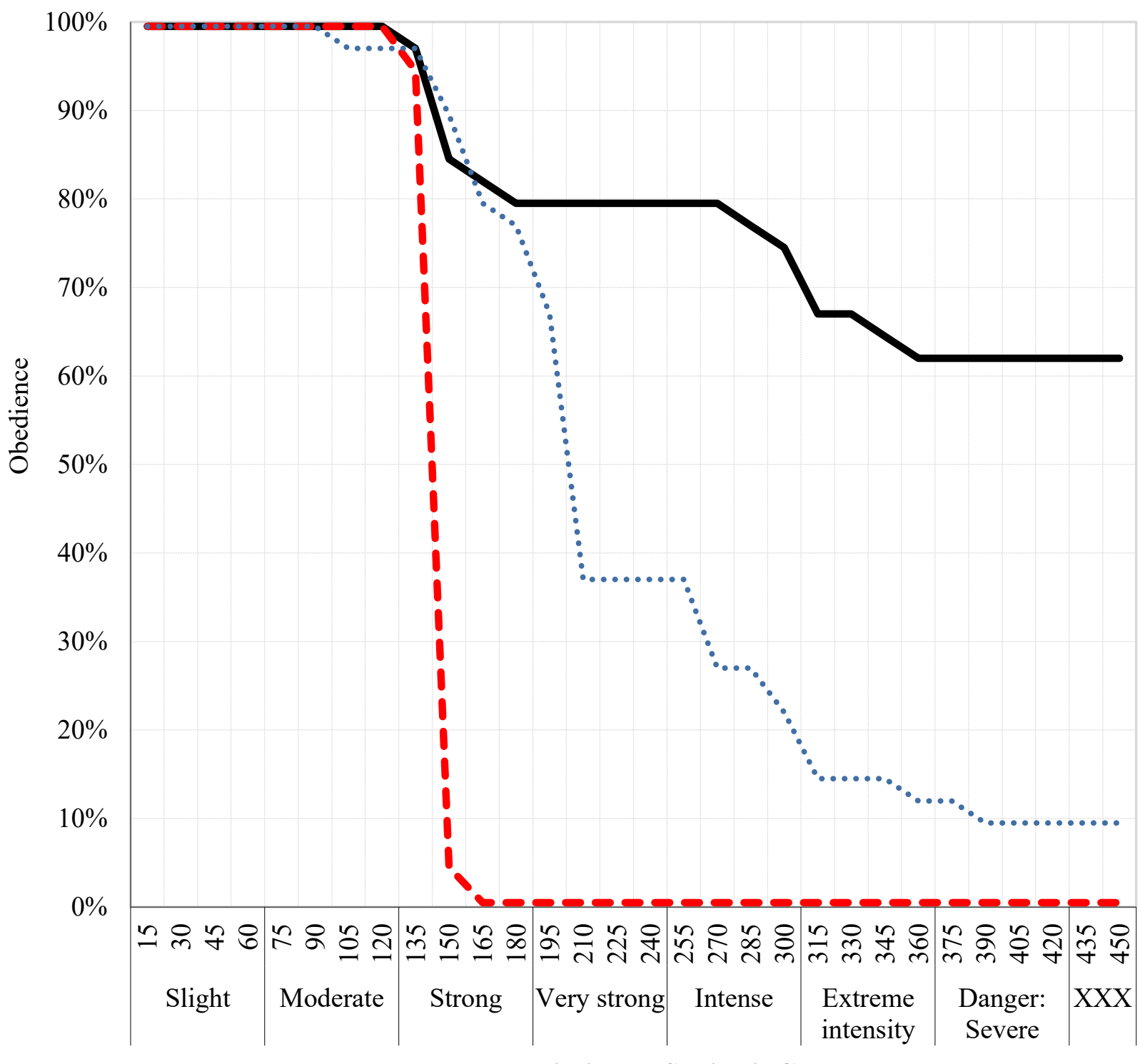

\section{Voltage and Description on Subject's Console}

Baseline

- Dissenting Second Psychologist

Dissenting Peer 


\section{Figure 2: Cumulative Abnormal Returns on News of Director Sudden Deaths}

Directors are classified as powerful (three of their four power centrality measures lie in their distributions' top quintiles) or not, and as legally independent (as reported by RiskMetrics) or not. This partitions decedent directors into four groups. Cumulative abnormal returns are total returns minus market model estimated returns using the CRSP value-weighted return to proxy for the market. Market model parameters are estimated using data from days -200 to -46 , with day 0 the date of the sudden death of one of its directors.

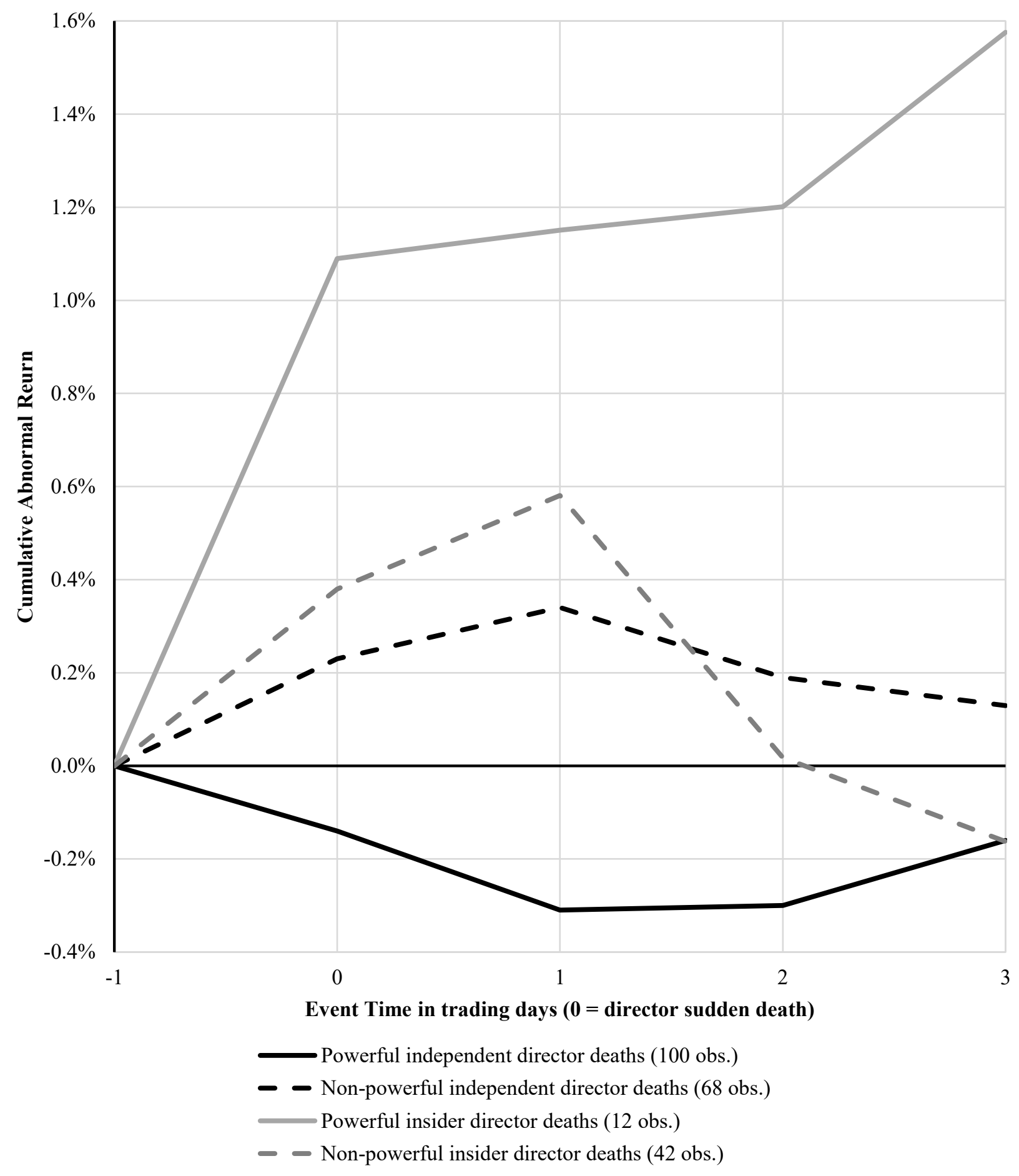




\section{Table 1: S\&P 1500 Officer and Director Power Centrality Measure Characteristics}

Power centrality measures are based on a social network whose nodes are individual directors and executives included in BoardEx. Connections between two individuals in the network form when they serve at the same firm in the same year and persist thereafter. The network is followed from 1998, when it has 191,049 individual nodes and 5,438,006 connections between nodes, to 2009, when it has 313,958 nodes and 11,639,006 connections. Each individual's four power centrality measures are: degree centrality (no. of direct connections), closeness centrality (mean degrees of separation from all others in the network), betweenness centrality (no. of shortest paths of connections linking other pairs of people that pass through her), and eigenvector centrality (a recursive measure in which each individual's social power as a weighted average of the social power of her direct connections). Statistics describe the 19,223 unique S\&P 1500 firm directors only, a panel of 132,020 director-years from 1998 to 2009. Panel A summarizes their raw power centrality measures; Panel B summarizes their power centralities' positions within the full network. Panel $\mathrm{C}$ presents Pearson correlation coefficients, clustered by individual, of individual-level centrality measures with each other. The upper triangle (above the diagonal line) uses raw measures and the lower triangle (numbers in italics) uses percentile measures. All correlation coefficients are significant at $1 \%$ or better. More detail is provided in Appendix Table A1.

Panel A: Characteristics of Raw Power Centrality Measures

\begin{tabular}{ccccccccc}
\hline & & Mean & Std. Dev. & Min & 25th & Median & 75th & Max \\
\hline Betweenness & $B_{i}$ & $0.00973 \%$ & $0.0229 \%$ & $0.00 \%$ & $0.000147 \%$ & $0.00216 \%$ & $0.00905 \%$ & $0.677 \%$ \\
Closeness & $C_{i}$ & $25.3 \%$ & $3.20 \%$ & $0.000688 \%$ & $23.2 \%$ & $25.4 \%$ & $27.6 \%$ & $34.4 \%$ \\
Degree & $D_{i}$ & 197 & 245 & 1 & 43 & 104 & 245 & 2,211 \\
Eigenvector & $E_{i}$ & $0.0581 \%$ & $0.371 \%$ & $0.00 \%$ & $0.000129 \%$ & $0.00213 \%$ & $0.0117 \%$ & $4.15 \%$
\end{tabular}

Panel B: S\&P Officer \& Director Power Centrality Measure Percentage Ranks

\begin{tabular}{ccccccccc}
\hline Betweenness & $b_{i}$ & 79.8 & 25.7 & 1 & 73 & 90 & 98 & 100 \\
Closeness & $c_{i}$ & 78.2 & 21.3 & 1 & 66 & 85 & 95 & 100 \\
Degree & $d_{i}$ & 77.0 & 22.4 & 1 & 63 & 86 & 95 & 100 \\
Eigenvector & $e_{i}$ & 76.5 & 20.9 & 1 & 65 & 81 & 94 & 100
\end{tabular}

Panel C: Pearson Correlation of CEO and Director Centrality Measures

\begin{tabular}{cccccc}
\hline & & Betweenness & Closeness & Degree & Eigenvector \\
\hline Betweenness & $b_{i}$ & 1.00 & 0.388 & 0.780 & 0.273 \\
Closeness & $c_{i}$ & 0.748 & 1.00 & 0.616 & 0.232 \\
Degree & $d_{i}$ & 0.809 & 0.887 & 1.00 & 0.501 \\
Eigenvector & $e_{i}$ & 0.677 & 0.942 & 0.813 & 1.00 \\
\hline
\end{tabular}




\section{Table 2: Variables and Definitions}

Variable

\section{Definition}

Measures of Director Independence and Power

Powerful Director (PD)

Director-level dummy set to 1 if at least 3 of director's 4 centrality measures are in their distributions' top quintile

Independent Director (ID)

Powerful Independent Director (PID)

Independent Board (IB)

Powerful Independent Board (PIB)

Fraction of directors independent (FID)

Independent Director Centrality (IDC) Annual firm-level mean of means of each independent director's highest 3 centrality measures

\begin{tabular}{|c|c|}
\hline \multicolumn{2}{|c|}{ Measures of Chair Independence and Power } \\
\hline Non-CEO Chair (NCC) & Annual firm-level dummy set to 1 if CEO does not chair board, 0 otherwise \\
\hline Non-CEO Chair Centrality (NCCC) & Annual firm-level mean of chair's top 3 percentile centrality measures if CEO is not chair, 0 otherwise \\
\hline Powerful Non-CEO Chair (PNC) & Annual firm-level dummy set to 1 if chair is powerful director $(\mathrm{PD}=1)$ and is not the $\mathrm{CEO}, 0$ otherwise \\
\hline \multicolumn{2}{|l|}{ Measures of CEO Power } \\
\hline Powerful CEO (PCEO) & $\begin{array}{l}\text { Annual firm-level dummy set to one if CEO is powerful, in that at least three of her four centrality measures are } \\
\text { in their distributions' top quintiles }\end{array}$ \\
\hline CEO Centrality (CEOC) & Annual firm-level variable equal to mean of the CEO's highest 3 percentile centrality measures \\
\hline \multicolumn{2}{|c|}{ Regression Variables (all are annual firm-level variables) } \\
\hline Tobin's Q (Q) & $\begin{array}{l}\text { Book value of assets minus book value of equity plus market value of equity minus deferred tax obligations, all } \\
\text { over book value of assets }\end{array}$ \\
\hline CEO Age (CEOA) & CEO age \\
\hline Board Size (BSIZE) & Total number of directors on board \\
\hline E-Index (ENDX) & Entrenchment Index (Bebchuk, Cohen, and Ferrell 2009) \\
\hline Assets (ASSETS) & Total assets, in billions of dollars \\
\hline Leverage (LEV) & Total debt over total assets \\
\hline Probability (PROF) & Net income over total assets \\
\hline Tangibility(TANG) & Property, Plant, and Equipment over total assets \\
\hline
\end{tabular}


Capital Investment(CAPEX)

Cash Flows(CF)

Research \& Development (R\&D)

Advertising (ADV)
Net Capital expenditure over last year's property, plant and equipment

The sum of net income, depreciation, and amortization over last year's property, plant and equipment

Research \& Development expense over total assets

Advertising expense over total assets

\begin{tabular}{|c|c|}
\hline \multicolumn{2}{|l|}{ Event Study Variables } \\
\hline Cumulative Abnormal Return (CAR) & Stock's daily return minus NYSE/AMSE/NASDAQ value-weighted market return, compounded \\
\hline Sudden Death (DEATH) & Firm dummy set to one on date of a powerful independent director sudden death, zero otherwise \\
\hline \multicolumn{2}{|c|}{ Measures of Independent Directors' Power in Specific Decisions } \\
\hline $\begin{array}{l}\text { Powerful Independent Nominating } \\
\text { Committee (PIBN) }\end{array}$ & Dummy set to 1 if majority nominating committee are powerful independent directors, 0 otherwise \\
\hline $\begin{array}{l}\text { Powerful Independent Auditing } \\
\text { Committee (PIBA) }\end{array}$ & Dummy set to 1 if majority auditing committee are powerful independent directors, 0 otherwise \\
\hline \multicolumn{2}{|l|}{ Other variables } \\
\hline Bidder Return (BRET) & Cumulative Abnormal Return between $[-3,+3]$ to a bidder upon merger announcement \\
\hline Combined Return (CRET) & $\begin{array}{l}\text { Cumulative Abnormal Return between }[-3,+3] \text { to the combined entity, calculated as the asset-weighted CARs of } \\
\text { the bidder and the target, upon merger announcement }\end{array}$ \\
\hline Free Cash Flow (FCF) & $\begin{array}{l}\text { Annual firm-level dummy set to } 1 \text { if cash flow exceeds 2-digit SIC industry median, dividend payout is below } 2 \text { - } \\
\text { digit SIC industry median, and Tobin's Q exceeds 2-digit SIC industry median. }\end{array}$ \\
\hline Stock Return (RET) & Annual firm-level variable equal to its stock's total return minus the CRSP value-weighted market total return \\
\hline Earnings Manipulation (EM) & Annual firm-level variable equal to absolute value of discretionary accruals, modified Jones model \\
\hline
\end{tabular}




\section{Table 3: Power Estimates for Directors, Independent Directors, Committees, Chairs and CEOs of S\&P 1500 Firms}

This table shows directors and CEOs in our sample to be relatively powerful compared to the general population of corporate officers and directors. No. firms is number of S\&P 1500 firms in the sample each year. Board characteristics include: PCEO is set to one if the CEO is designated as powerful - i.e. at least three of her four power centrality measures lie in the top quintiles of their overall distributions. $P C E O$ is one if the CEO is designated as powerful. BSIZE is the number of directors on the board; NID is the number of directors designated independent in the firm's SEC filings, and $I B$ is 1 for firms with a majority of independent directors and 0 otherwise. $N P I D / I D$ is the fraction of independent directors designated as powerful and $P I B$ is one for independent boards in which a majority of independent directors are powerful. Board chair characteristics are: NCC, set to 1 if the CEO is not the chair and to 0 otherwise, and PNC, set to 1 if NCC is one and if the non-CEO chair is designated as powerful. Board committee characteristics are the means of dummies set to one if majorities of the Audit, Compensation and Nominating Committee members are powerful independent directors.

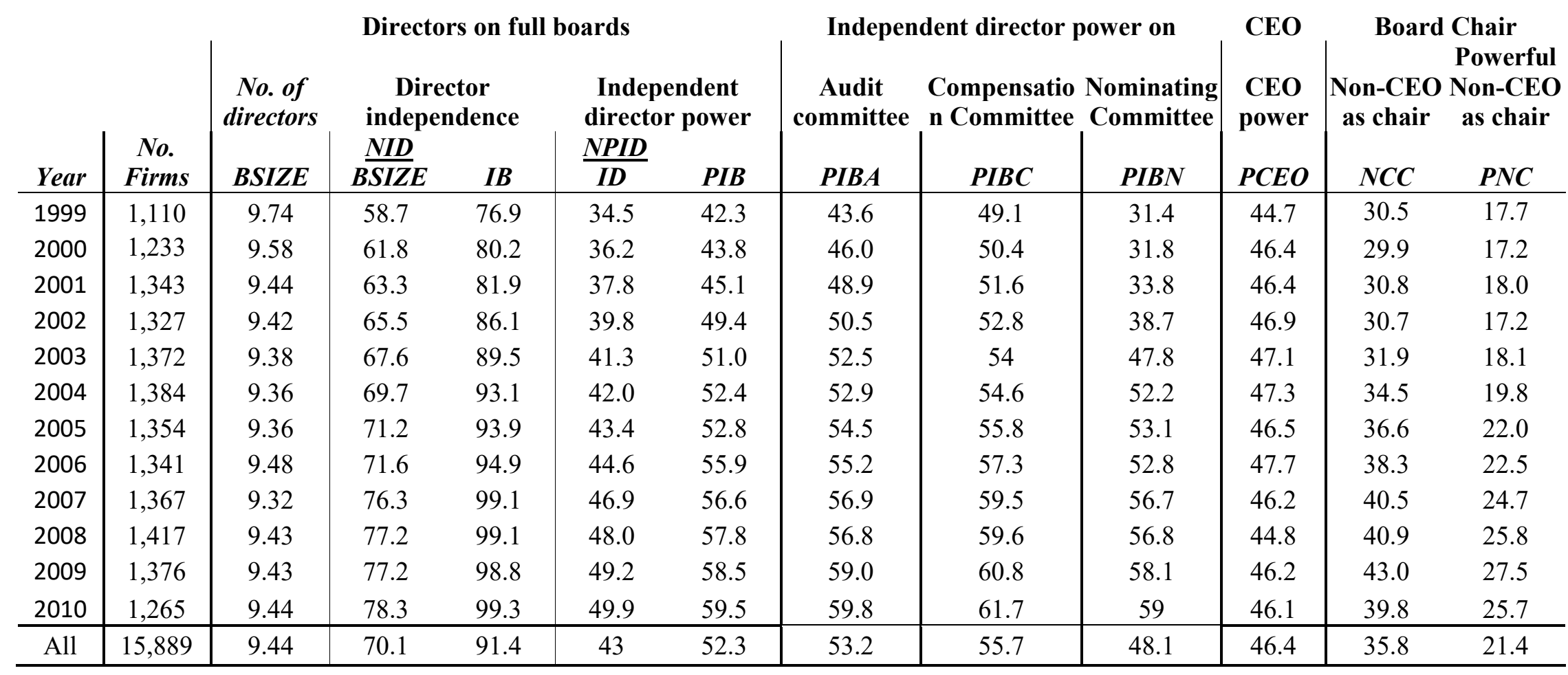


Table 4: Firm Value, Powerful Independent Directors, and a Powerful Non-CEO as Chair

Shareholder valuation, measured by Tobin's Q (Q) from 1999 to 2010 explained with OLS regressions on one-year lagged measures of CEO, chair, and independent director presence and power as well control variables including industry and year fixed-effects. Variables are as described in Table 2. Sample is a 13,933 observation annual panel of S\&P 1500 firms. Numbers in parentheses are robust p-levels clustering by firm. Boldface denotes significance at $10 \%$ or better.

\begin{tabular}{|c|c|c|c|c|c|c|c|c|}
\hline Regression & 4.1 & 4.2 & 4.3 & 4.4 & 4.5 & 4.6 & 4.7 & 4.8 \\
\hline $\begin{array}{l}\text { Powerful independent } \\
\text { board dummy (PIB) }\end{array}$ & $\begin{array}{c}0.0658 \\
(0.04)\end{array}$ & & & & & & $\begin{array}{c}\mathbf{0 . 0 5 5 7} \\
(\mathbf{0 . 1 0 )}\end{array}$ & \\
\hline $\begin{array}{l}\text { Independent director } \\
\text { power centrality } \\
\text { (IDC) }\end{array}$ & & $\begin{array}{c}0.00254 \\
(0.04)\end{array}$ & & & & & & $\begin{array}{c}0.00322 \\
(0.04)\end{array}$ \\
\hline $\begin{array}{c}\text { Powerful CEO } \\
\text { dummy (PCEO) }\end{array}$ & & & $\begin{array}{c}0.0364 \\
(0.26)\end{array}$ & & & & $\begin{array}{c}0.0224 \\
(0.50)\end{array}$ & \\
\hline $\begin{array}{l}\text { Powerful non-CEO } \\
\text { chair (PNC) }\end{array}$ & & & & $\begin{array}{l}0.0499 \\
(0.16)\end{array}$ & & & $\begin{array}{c}0.0429 \\
(0.23)\end{array}$ & \\
\hline $\begin{array}{c}\text { CEO power centrality } \\
\text { (CEOC) }\end{array}$ & & & & & $\begin{array}{c}0.000189 \\
(0.84)\end{array}$ & & & $\begin{array}{c}-0.00105 \\
(0.35)\end{array}$ \\
\hline $\begin{array}{l}\text { Non-CEO chair } \\
\text { power centrality } \\
\text { (NCCC) }\end{array}$ & & & & & & $\begin{array}{c}0.000179 \\
(0.63)\end{array}$ & & $\begin{array}{c}0.000106 \\
(0.78)\end{array}$ \\
\hline log (ceo age) & $\begin{array}{l}-0.160 \\
(0.14)\end{array}$ & $\begin{array}{l}-0.148 \\
(0.17)\end{array}$ & $\begin{array}{r}-0.183 \\
(0.09)\end{array}$ & $\begin{array}{l}-0.156 \\
(0.14)\end{array}$ & $\begin{array}{l}-0.180 \\
(0.09)\end{array}$ & $\begin{array}{l}-0.169 \\
(0.12)\end{array}$ & $\begin{array}{l}-0.143 \\
(0.19)\end{array}$ & $\begin{array}{l}-0.138 \\
(0.21)\end{array}$ \\
\hline $\log ($ board & $\begin{array}{r}-0.312 \\
(0.00)\end{array}$ & $\begin{array}{r}-0.311 \\
(0.00)\end{array}$ & $\begin{array}{r}-0.303 \\
(0.00)\end{array}$ & $\begin{array}{l}-0.309 \\
(0.00)\end{array}$ & $\begin{array}{l}-0.302 \\
(0.00)\end{array}$ & $\begin{array}{l}-0.305 \\
(0.00)\end{array}$ & $\begin{array}{c}-0.318 \\
(0.00)\end{array}$ & $\begin{array}{l}-0.310 \\
(0.00)\end{array}$ \\
\hline e-index & $\begin{array}{c}-0.0605 \\
(0.00)\end{array}$ & $\begin{array}{c}-0.0601 \\
(0.00)\end{array}$ & $\begin{array}{c}-0.0597 \\
(0.00)\end{array}$ & $\begin{array}{c}-0.0589 \\
(0.00)\end{array}$ & $\begin{array}{c}-0.0593 \\
(0.00)\end{array}$ & $\begin{array}{c}-0.0588 \\
(0.00)\end{array}$ & $\begin{array}{c}-0.0605 \\
(0.00)\end{array}$ & $\begin{array}{c}-0.0592 \\
(0.00)\end{array}$ \\
\hline $\log$ (total assets) & $\begin{array}{c}-0.0470 \\
(0.00)\end{array}$ & $\begin{array}{c}-0.0502 \\
(0.00)\end{array}$ & $\begin{array}{c}-0.0433 \\
(0.00)\end{array}$ & $\begin{array}{c}-0.0382 \\
(0.01)\end{array}$ & $\begin{array}{c}-\mathbf{0 . 0 3 9 3} \\
(0.01)\end{array}$ & $\begin{array}{c}-0.0377 \\
(\mathbf{0 . 0 1})\end{array}$ & $\begin{array}{c}-0.0487 \\
(0.00)\end{array}$ & $\begin{array}{c}-0.0469 \\
(0.00)\end{array}$ \\
\hline book lev & $\begin{array}{l}-0.136 \\
(0.26)\end{array}$ & $\begin{array}{r}-0.140 \\
(0.25)\end{array}$ & $\begin{array}{l}-0.137 \\
(0.26)\end{array}$ & $\begin{array}{l}-0.138 \\
(0.26)\end{array}$ & $\begin{array}{l}-0.137 \\
(0.26)\end{array}$ & $\begin{array}{l}-0.137 \\
(0.26)\end{array}$ & $\begin{array}{l}-0.138 \\
(0.26)\end{array}$ & $\begin{array}{l}-0.140 \\
(0.25)\end{array}$ \\
\hline profitability & $\begin{array}{l}5.376 \\
(0.00)\end{array}$ & $\begin{array}{l}5.377 \\
(0.00)\end{array}$ & $\begin{array}{l}5.384 \\
(0.00)\end{array}$ & $\begin{array}{l}5.393 \\
(0.00)\end{array}$ & $\begin{array}{l}5.391 \\
(0.00)\end{array}$ & $\begin{array}{l}5.393 \\
(0.00)\end{array}$ & $\begin{array}{l}5.374 \\
(0.00)\end{array}$ & $\begin{array}{l}5.378 \\
(0.00)\end{array}$ \\
\hline investment & $\begin{array}{l}0.806 \\
(0.01)\end{array}$ & $\begin{array}{l}0.821 \\
(0.01)\end{array}$ & $\begin{array}{r}0.796 \\
(0.01)\end{array}$ & $\begin{array}{l}0.782 \\
(0.01)\end{array}$ & $\begin{array}{r}0.784 \\
(0.01)\end{array}$ & $\begin{array}{l}0.782 \\
(0.01)\end{array}$ & $\begin{array}{l}0.813 \\
(0.01)\end{array}$ & $\begin{array}{l}0.813 \\
(0.01)\end{array}$ \\
\hline R\&D/total assets & $\begin{array}{l}8.596 \\
(0.00)\end{array}$ & $\begin{array}{l}8.569 \\
(0.00)\end{array}$ & $\begin{array}{l}8.674 \\
(0.00)\end{array}$ & $\begin{array}{l}8.694 \\
(0.00)\end{array}$ & $\begin{array}{l}8.733 \\
(\mathbf{0 . 0 0})\end{array}$ & $\begin{array}{c}8.738 \\
(0.00)\end{array}$ & $\begin{array}{l}8.524 \\
(0.00)\end{array}$ & $\begin{array}{l}8.609 \\
(0.00)\end{array}$ \\
\hline $\begin{array}{c}\text { advertising / total } \\
\text { assets }\end{array}$ & $\begin{array}{l}1.736 \\
(0.05)\end{array}$ & $\begin{array}{c}1.723 \\
(\mathbf{0 . 0 5})\end{array}$ & $\begin{array}{l}1.767 \\
(\mathbf{0 . 0 5})\end{array}$ & $\begin{array}{c}1.821 \\
(0.04)\end{array}$ & $\begin{array}{c}1.798 \\
(0.04)\end{array}$ & $\begin{array}{l}1.820 \\
(0.04)\end{array}$ & $\begin{array}{l}1.739 \\
(0.05)\end{array}$ & $\begin{array}{c}1.740 \\
(0.05)\end{array}$ \\
\hline Industry fixed-effects & $\mathrm{Y}$ & Y & Y & $\mathrm{Y}$ & $\mathrm{Y}$ & Y & $\mathrm{Y}$ & Y \\
\hline Year fixed-effects & $\mathrm{Y}$ & $\mathrm{Y}$ & $\mathrm{Y}$ & $\mathrm{Y}$ & $\mathrm{Y}$ & $\mathrm{Y}$ & $\mathrm{Y}$ & $\mathrm{Y}$ \\
\hline$R^{2}$ & 0.388 & 0.388 & 0.388 & 0.388 & 0.388 & 0.388 & 0.388 & 0.388 \\
\hline
\end{tabular}




\section{Table 5: Legally Independent Directors versus Powerful Independent Directors}

OLS regressions explaining Tobin's Q (Q) with measures of directors' legal independence and independent directors' power, as well as all control variables from Table 4 and industry and year fixed-effects (not shown). Variables are as described in Table 2. Sample is a 13,933 firm-year panel of S\&P 1500 firms from 1999 to 2010. Numbers in parentheses are robust p-levels clustering by firm. Boldface denotes significance at $10 \%$ or better.

\begin{tabular}{|c|c|c|c|c|c|c|c|}
\hline Regression & 5.1 & 5.2 & 5.3 & 5.4 & 5.5 & 5.6 & 5.7 \\
\hline $\begin{array}{c}\text { Powerful independent board } \\
\text { dummy (PIB) }\end{array}$ & & & & & & $\begin{array}{r}0.104 \\
(0.00)\end{array}$ & $\begin{array}{l}\mathbf{0 . 1 0 2} \\
(0.00)\end{array}$ \\
\hline $\begin{array}{l}\text { Fraction of directors } \\
\text { Independent (FID) }\end{array}$ & $\begin{array}{r}-0.211 \\
(0.02)\end{array}$ & & & & $\begin{array}{l}-0.335 \\
(0.02)\end{array}$ & $\begin{array}{r}-0.302 \\
(0.00)\end{array}$ & $\begin{array}{r}-0.384 \\
(0.01)\end{array}$ \\
\hline $\begin{array}{c}\text { Majority of directors } \\
\text { independent dummy (IB) }\end{array}$ & & $\begin{array}{c}-0.0521 \\
(0.30)\end{array}$ & & & $\begin{array}{c}0.0461 \\
(0.42)\end{array}$ & & $\begin{array}{c}0.0152 \\
(0.79)\end{array}$ \\
\hline $\begin{array}{l}\text { Two-thirds of directors } \\
\text { independent dummy }\end{array}$ & & & $\begin{array}{c}-0.0517 \\
(0.12)\end{array}$ & & $\begin{array}{c}0.0346 \\
(0.42)\end{array}$ & & $\begin{array}{c}0.0309 \\
(0.47)\end{array}$ \\
\hline $\begin{array}{l}\text { CEO does not chair the board } \\
\text { dummy (NCC) }\end{array}$ & & & & $\begin{array}{c}-0.0101 \\
(0.74)\end{array}$ & $\begin{array}{c}-0.0187 \\
(0.54)\end{array}$ & & $\begin{array}{c}-0.0187 \\
(0.54)\end{array}$ \\
\hline Control variables & Y & Y & $\mathrm{Y}$ & $\mathrm{Y}$ & $\mathrm{Y}$ & $\mathrm{Y}$ & $\mathrm{Y}$ \\
\hline Industry fixed-effects & $\mathrm{Y}$ & $\mathrm{Y}$ & Y & $\mathrm{Y}$ & Y & $\mathrm{Y}$ & $\mathrm{Y}$ \\
\hline Year fixed-effects & $\mathrm{Y}$ & Y & $\mathrm{Y}$ & $\mathrm{Y}$ & Y & $\mathrm{Y}$ & $\mathrm{Y}$ \\
\hline Adjusted R-squared & 0.389 & 0.388 & 0.388 & 0.388 & 0.389 & 0.390 & 0.390 \\
\hline
\end{tabular}




\section{Table 6: Cumulative Abnormal Returns on Powerful Independent Director Sudden Deaths}

Cumulative abnormal returns (CARs), in percent, for windows [-1, 1], [-1, 2], [-1, 3], and [-3, 3], with $t=$ 0 the first news of the director's sudden death and $\left[t_{1}, t_{2}\right]$ a window from $t_{1}$ to $t_{2}$. CARs are actual returns less market model estimates, parameters estimated using $t=-200$ to -46 , using the CRSP value-weighted total market return (Panel A) and both the equal- and value-weighted CRSP total market return (Panel B).

\section{Panel A: Mean Cumulative Abnormal Returns on Director Sudden Deaths}

Boldface indicates means significantly different from zero at $10 \%$ or better. Numbers in parenthesis are pvalues for $\mathrm{t}$-test statistics rejecting equal group means, with boldface indicating significance level $10 \%$ or better.

\begin{tabular}{|c|c|c|c|c|c|c|c|c|c|}
\hline \multirow{2}{*}{$\begin{array}{c}\text { Decedents: } \\
\text { Test: } \\
\text { Window }\end{array}$} & \multicolumn{3}{|c|}{$\begin{array}{c}\text { All directors } \\
\text { Decedent is independent? }\end{array}$} & \multicolumn{3}{|c|}{$\begin{array}{l}\text { Independent directors } \\
\text { Decedent is powerful? }\end{array}$} & \multicolumn{3}{|c|}{$\begin{array}{l}\text { Non-independent directors } \\
\text { Decedent is powerful? }\end{array}$} \\
\hline & Yes & No & Difference & Yes & No & Difference & Yes & No & Difference \\
\hline$[-1,+1]$ & $\begin{array}{c}-0.0018 \\
(0.31)\end{array}$ & $\begin{array}{l}0.618 \\
(0.09)\end{array}$ & $\begin{array}{l}-0.620 \\
(0.13)\end{array}$ & $\begin{array}{r}-0.286 \\
(0.08)\end{array}$ & $\begin{array}{l}0.416 \\
(0.17)\end{array}$ & $\begin{array}{r}-0.702 \\
(0.10)\end{array}$ & $\begin{array}{c}1.65 \\
(0.02)\end{array}$ & $\begin{array}{l}0.322 \\
(0.34)\end{array}$ & $\begin{array}{c}1.33 \\
(0.12)\end{array}$ \\
\hline$[-1,+2]$ & $\begin{array}{l}0.0854 \\
(0.44)\end{array}$ & $\begin{array}{l}0.219 \\
(0.24)\end{array}$ & $\begin{array}{r}-0.134 \\
(0.41)\end{array}$ & $\begin{array}{l}-0.247 \\
(0.13)\end{array}$ & $\begin{array}{l}0.574 \\
(0.14)\end{array}$ & $\begin{array}{r}-0.821 \\
(0.09)\end{array}$ & $\begin{array}{l}1.60 \\
(0.02)\end{array}$ & $\begin{array}{l}-0.177 \\
(0.39)\end{array}$ & $\begin{array}{l}1.78 \\
(0.08)\end{array}$ \\
\hline$[-1,+3]$ & $\begin{array}{l}0.0589 \\
(0.45)\end{array}$ & $\begin{array}{l}0.158 \\
(0.26)\end{array}$ & $\begin{array}{c}-0.0991 \\
(0.44)\end{array}$ & $\begin{array}{l}-0.237 \\
(0.18)\end{array}$ & $\begin{array}{l}0.494 \\
(0.19)\end{array}$ & $\begin{array}{l}-0.731 \\
(0.17)\end{array}$ & $\begin{array}{c}1.86 \\
(\mathbf{0 . 0 3})\end{array}$ & $\begin{array}{l}-0.329 \\
(0.40)\end{array}$ & $\begin{array}{c}2.19 \\
(0.01)\end{array}$ \\
\hline$[-3,+3]$ & $\begin{array}{l}-0.163 \\
(0.20)\end{array}$ & $\begin{array}{l}0.165 \\
(0.25)\end{array}$ & $\begin{array}{l}-0.328 \\
(0.35)\end{array}$ & $\begin{array}{l}-0.345 \\
(0.15)\end{array}$ & $\begin{array}{l}0.105 \\
(0.48)\end{array}$ & $\begin{array}{l}-0.45 \\
(0.30)\end{array}$ & $\begin{array}{c}1.95 \\
(0.03)\end{array}$ & $\begin{array}{l}-0.346 \\
(0.40)\end{array}$ & $\begin{array}{c}2.30 \\
(0.02)\end{array}$ \\
\hline Events & 168 & 54 & 222 & 100 & 68 & 168 & 12 & 42 & 54 \\
\hline
\end{tabular}

Panel B: OLS Regressions of CARs on Decedent Director Independence and Power Indicators

CARs around 222 director sudden deaths regressed on dummies for decedent director being powerful, legally independent or both, controlling for director age at death and firm characteristics as in Table 4. Probability levels, in parentheses, are bold for significance at $10 \%$ or better.

\begin{tabular}{|c|c|c|c|c|c|c|c|c|}
\hline Regression & 6B.1 & 6B.2 & 6B.3 & 6B.4 & 6B.5 & 6B.6 & 6B.7 & 6B.8 \\
\hline $\begin{array}{l}\text { Market return } \\
\text { weights }\end{array}$ & equal & equal & Equal & equal & value & value & value & value \\
\hline Event window & {$[-1,+1]$} & {$[-1,+2]$} & {$[-1,+3]$} & {$[-3,+3]$} & {$[-1,+1]$} & {$[-1,+2]$} & {$[-1,+3]$} & {$[-3,+3]$} \\
\hline $\begin{array}{l}\text { Powerful director } \\
\text { (PD) }\end{array}$ & $\begin{array}{c}2.43 \\
(0.02)\end{array}$ & $\begin{array}{c}3.16 \\
(0.01)\end{array}$ & $\begin{array}{c}3.87 \\
(\mathbf{0 . 0 0})\end{array}$ & $\begin{array}{c}4.41 \\
(0.00)\end{array}$ & $\begin{array}{c}1.58 \\
(0.15)\end{array}$ & $\begin{array}{l}2.00 \\
(0.12)\end{array}$ & $\begin{array}{c}2.50 \\
(0.05)\end{array}$ & $\begin{array}{c}2.99 \\
(0.03)\end{array}$ \\
\hline $\begin{array}{l}\text { Independent } \\
\text { director (ID) }\end{array}$ & $\begin{array}{c}0.18 \\
(0.83)\end{array}$ & $\begin{array}{c}0.93 \\
(0.28)\end{array}$ & $\begin{array}{l}1.56 \\
(0.08)\end{array}$ & $\begin{array}{l}1.25 \\
(0.26)\end{array}$ & $\begin{array}{l}-0.10 \\
(0.90)\end{array}$ & $\begin{array}{c}0.64 \\
(0.45)\end{array}$ & $\begin{array}{l}1.18 \\
(0.19)\end{array}$ & $\begin{array}{c}0.77 \\
(0.48)\end{array}$ \\
\hline $\begin{array}{c}\text { Powerful } \\
\text { independent } \\
\text { director (PID) }\end{array}$ & $\begin{array}{l}-3.57 \\
(0.01)\end{array}$ & $\begin{array}{r}-04.69 \\
(0.00)\end{array}$ & $\begin{array}{l}-5.74 \\
(0.00)\end{array}$ & $\begin{array}{l}-6.20 \\
(0.00)\end{array}$ & $\begin{array}{l}-2.59 \\
(0.05)\end{array}$ & $\begin{array}{l}-3.47 \\
(0.01)\end{array}$ & $\begin{array}{l}-4.27 \\
(0.00)\end{array}$ & $\begin{array}{l}-4.51 \\
(0.01)\end{array}$ \\
\hline $\mathbf{R}^{2}$ & 0.124 & 0.221 & 0.238 & 0.257 & 0.105 & 0.181 & 0.198 & 0.204 \\
\hline
\end{tabular}




\section{Table 7: Channels of Value Addition by Powerful Independent Boards}

\section{Panel A: Value Destroying M\&A and CEO turnover}

In columns 7A.1 and 7A.2, cumulative abnormal returns from day -3 to day +3 around dates of M\&A announcement by S\&P 1500 firms between 1999 and 2010, explained by OLS regressions on measures of $\mathrm{CEO}$ and independent director power as well as control variables, including industry and year fixed-effects. In columns 7A.3 and 7A.4, binomial probit regressions explain log odds of a forced CEO turnover with the powerful independent board dummy PIB and their analogs for the nominating committee, PIBN - along with their interactions with the prior year's total stock return, RET and control variables including industry and year fixed-effects. The forced CEO turnover dummy is set to one if a new CEO is brought in from outside the firm during the year and to zero otherwise. Sample includes 212 forced turnover events and 394 non-forced turnover events from 1999 to 2010.

\begin{tabular}{|c|c|c|c|c|}
\hline Regression & 7A.1 & 7A.2 & 7A.3 & $7 \mathrm{A.4}$ \\
\hline \multirow{2}{*}{ Explained variable } & \multicolumn{2}{|c|}{$\operatorname{CAR}[-3,+3]$} & \multirow{2}{*}{\multicolumn{2}{|c|}{ CEO Turnover }} \\
\hline & Bidder & Combined & & \\
\hline Power measure & PIB & PIB & PIB & PIBN \\
\hline Power & $\begin{array}{c}1.55 \\
(0.04)\end{array}$ & $\begin{array}{c}1.48 \\
(0.04)\end{array}$ & $\begin{array}{l}-0.217 \\
(0.00)\end{array}$ & $\begin{array}{r}-0.212 \\
(0.01)\end{array}$ \\
\hline Power $\times R_{E T T^{a}}$ & & & $\begin{array}{l}-0.52 \\
(0.06)\end{array}$ & $\begin{array}{l}-0.611 \\
(0.04)\end{array}$ \\
\hline RET & & & $\begin{array}{c}-0.00511 \\
(0.98)\end{array}$ & $\begin{array}{c}-0.0543 \\
(0.73)\end{array}$ \\
\hline PCEO & $\begin{array}{l}-3.46 \\
(0.00)\end{array}$ & $\begin{array}{l}-3.04 \\
(0.00)\end{array}$ & & \\
\hline Log (CEO age) & $\begin{array}{c}7.21 \\
(0.01)\end{array}$ & $\begin{array}{c}3.87 \\
(0.14)\end{array}$ & $\begin{array}{l}-0.472 \\
(0.39)\end{array}$ & $\begin{array}{l}-0.463 \\
(0.40)\end{array}$ \\
\hline Log(board size) & $\begin{array}{l}-0.316 \\
(0.77)\end{array}$ & $\begin{array}{l}-1.66 \\
(0.11)\end{array}$ & $\begin{array}{l}-0.287 \\
(0.24)\end{array}$ & $\begin{array}{l}-0.277 \\
(0.27)\end{array}$ \\
\hline e-index & $\begin{array}{l}0.209 \\
(0.35)\end{array}$ & $\begin{array}{l}0.297 \\
(0.17)\end{array}$ & $\begin{array}{c}-0.0197 \\
(0.64)\end{array}$ & $\begin{array}{c}-0.0237 \\
(0.57)\end{array}$ \\
\hline Same industry dummy & $\begin{array}{l}-0.513 \\
(0.43)\end{array}$ & $\begin{array}{l}-0.329 \\
(0.60)\end{array}$ & & \\
\hline Stock payment dummy & $\begin{array}{l}-1.74 \\
(0.02)\end{array}$ & $\begin{array}{c}-.169 \\
(0.02)\end{array}$ & & \\
\hline Deal value & $\begin{array}{c}-3.31 \\
(\mathbf{0 . 0 0 )}\end{array}$ & $\begin{array}{c}2.83 \\
(0.05)\end{array}$ & & \\
\hline Observations & 632 & 632 & 606 & 606 \\
\hline $\mathbf{R}^{2}$ & 0.0592 & 0.0406 & 0.0494 & 0.0499 \\
\hline
\end{tabular}




\section{Panel B: Free Cash Flow Agency Problems and Earnings Manipulation}

In columns 7B.1 and 7B.2, probit regressions of a free cash flow "danger signal" dummy on CEO, chair, and independent director power, with controls and industry and year fixed-effects. The free cash flow "danger signal" dummy is set to one if the firm's cash flow exceeds its Fama-French 17-industry (FF-17) median, its dividend payout is below its FF-17 median, and its Tobin's Q is below its FF-17 median; and to zero otherwise. In columns 7B.3 and 7B.4, OLS regressions explain the absolute value of the modified Jones model discretionary accruals with the powerful independent board dummy PIB and their analogs for the audit committee, PIBA. All regressions include control variables and industry and year fixed-effects. Sample is 13,933 firm-years of S\&P 1500 firms from 1999 to 2010. Numbers in parentheses are robust plevels clustering by firm. Boldface denotes significance at $10 \%$ or better.

\begin{tabular}{|c|c|c|c|c|}
\hline Regression & 7B.1 & $7 B .2$ & 7B.3 & $7 B .4$ \\
\hline \multirow{2}{*}{$\begin{array}{c}\text { Explained variable } \\
\text { Power measure }\end{array}$} & \multicolumn{2}{|c|}{ Free Cash Flow } & \multicolumn{2}{|c|}{ Earning Management (EM) } \\
\hline & PIB & PIB & PIB & PIBA \\
\hline Power & $\begin{array}{r}-0.217 \\
(0.00)\end{array}$ & $\begin{array}{c}-0.212 \\
(0.01)\end{array}$ & $\begin{array}{c}-0.00402 \\
(0.05)\end{array}$ & $\begin{array}{c}-0.00326 \\
(0.11)\end{array}$ \\
\hline PCEO & & $\begin{array}{c}-0.0169 \\
(0.82)\end{array}$ & & \\
\hline log (CEO age) & $\begin{array}{l}0.107 \\
(0.65)\end{array}$ & $\begin{array}{l}0.109 \\
(0.64)\end{array}$ & $\begin{array}{c}0.0273 \\
(0.00)\end{array}$ & $\begin{array}{c}\mathbf{0 . 0 2 7 7} \\
(\mathbf{0 . 0 0 )}\end{array}$ \\
\hline $\log$ (board size) & $\begin{array}{c}0.0961 \\
(0.51)\end{array}$ & $\begin{array}{c}0.0959 \\
(0.51)\end{array}$ & $\begin{array}{c}0.00379 \\
(0.41)\end{array}$ & $\begin{array}{c}0.00345 \\
(0.45)\end{array}$ \\
\hline e-index & $\begin{array}{c}-0.0153 \\
(0.57)\end{array}$ & $\begin{array}{c}-0.0152 \\
(0.58)\end{array}$ & $\begin{array}{c}-0.000197 \\
(0.78)\end{array}$ & $\begin{array}{c}-0.000246 \\
(0.73)\end{array}$ \\
\hline $\log$ (total assets) & $\begin{array}{c}0.0161 \\
(0.56)\end{array}$ & $\begin{array}{c}0.0174 \\
(0.53)\end{array}$ & $\begin{array}{c}0.000728 \\
(0.47)\end{array}$ & $\begin{array}{c}0.000638 \\
(0.53)\end{array}$ \\
\hline book leverage & $\begin{array}{r}-0.432 \\
(0.02)\end{array}$ & $\begin{array}{l}-0.429 \\
(0.02)\end{array}$ & $\begin{array}{l}0.00395 \\
(0.62)\end{array}$ & $\begin{array}{c}0.00408 \\
(0.61)\end{array}$ \\
\hline profitability & $\begin{array}{c}-0.600 \\
(0.08)\end{array}$ & $\begin{array}{c}-0.592 \\
(0.09)\end{array}$ & $\begin{array}{l}0.067 \\
(0.00)\end{array}$ & $\begin{array}{c}0.0671 \\
(0.00)\end{array}$ \\
\hline investment & $\begin{array}{c}1.00 \\
(0.02)\end{array}$ & $\begin{array}{l}0.997 \\
(0.02)\end{array}$ & $\begin{array}{l}-0.114 \\
(0.00)\end{array}$ & $\begin{array}{l}-0.114 \\
(0.00)\end{array}$ \\
\hline $\mathbf{R}^{2}$ & 0.0489 & 0.049 & 0.0373 & 0.0372 \\
\hline
\end{tabular}

a. Probit interactions are interpreted as distributional changes in implied conditional probabilities. See text for details 


\section{Appendix}

Appendix Tables A1 provides more details about the social network. Appendix table A2 provides details about variables used in this appendix, but not in the body of the paper. Appendix Table A3 provides summary statistics for all variables. The remainder of the appendix elaborates on the robustness section 5 and tabulates key robustness check results.

\section{A1. General robustness checks}

The results are not driven by outliers. All continuous variables are windsorized, and outlier tests reveal no observations with undue influence. The regressions cluster standard errors by firm to control for firm-level persistence and include industry fixed-effects to control for unobserved time-invariant latent industry-level factors. Clustering by industry, which also allows for cross-correlations among firms within each industry, generates qualitatively similar results to those in the tables.

\section{A2. Robustness to alternative construction of power measures}

The results in the tables do not depend on precicely how we build the social network. The power centrality measures used to construct the variables in the tables assume connections formed one year persist thereafter. As robustness checks, we construct alternative networks assuming connections form only after three years of overlap, assuming connections break after five years of non-overlap, and both. Qualitatively similar results to those in the tables ensue in each case.

The results in the tables are not driven by the precise ways we define or aggregate individuals' social power. The tables define a powerful independent director (PID) as having at least three of the four centrality measures in the top quintiles of their empirical distributions. Using the top $15 \%$ or $25 \%$, rather than top quintiles, of the distributions also generates qualitatively similar results. Requiring all four, rather than just three of the four, power centrality measures to be in their top quintiles to classify an individual as powerful cuts the number of powerful independent directors, but generates qualitatively similar results and many significance levels improve.

The continuous power centrality measures for a firm's independent directors (IDC) generates qualitatively similar results to those in the tables using PIB to assess independent director power. The continuous power measures for independent directors (IDC), an independent director serving as chair (NCCC), and the CEO (CEOC) in the tables are means of these individuals' three highest social power measures. Using means of all four of their power centrality measures instead yields similar signs and magnitudes, though some fall below significance thresholds. Principal components analysis is another approach to combining the four power centralities into a single summary measure for each individual. At the director-year level, the first principal component of the rescaled power centrality measures $\left(b_{i}, c_{i}, d_{i}\right.$ and $e_{i}$ ) captures $86 \%$ of their variation and that of the raw power centrality measures $\left(B_{i}, C_{i}, D_{i}\right.$ and $E_{i}$ ) captures 
$62 \%$ of their variation. In both cases, the first principal component approximates an equal-weighted mean of the four individual measures. Using either set of first principal component values to generate analogs of the independent director and CEO continuous power measures, IDC and CEOC, generates results qualitatively similar to those in the tables.

The powerful independent board dummy $(P I B)$ is one if the board has a majority of independent directors and if a majority of these are powerful and zero otherwise. Requiring 3/5, 2/3, 3/4, or $4 / 5$ of independent directors to be powerful for the $P I B$ to be one generates qualitatively similar results to the tables. Using a PID ratio, defined as the fraction of independent directors who are powerful, also yields results qualitatively similar to the tables.

\section{A3. Robustness to controlling for other director characteristics}

Section 5 describes how controlling for other director characteristics - e.g. experience (Kang 2013), equity ownership (Bhagat and Bolton 2013), intensive monitoring (Faleye et al. 2011), and busyness (Ferris et al. 2003; Fich and Shivdasani 2006) generates results qualitatively similar to the tables. The last, like our power measures, is constructed from a social network and so merits further investigation. Fich and Shivdasani (2006) define as a board as busy if a majority of its independent directors serve on three or more other boards. This is similar to a degree power centrality (number of direct connection) in a network of current connection to the boards of other firms in the sample. Using a network of only currentyear interlocks between S\&P 1500 boards does not yield our results. Expanding the network in stages to restore the one used in the tables helps clarify which of these differences are most important. Using a network of current connections, but not past ones, at all listed firms (S\&P 1500 firms and non-S\&P1500 firms) generates results more qualitatively similar to those in our tables, though the PIB interaction with prior return loses significance in explaining forced CEO turnover in analogs to regressions 7A.3 and 7A.4 in Table 7. Using a network of current and past connections, but based on positions at large (S\&P1500) firms only, preserves some results, but $I D C$ loses significance in Table 4. As noted above, using only current interlocks at S\&P1500 firms - that is, dropping both past connections and connections formed at nonS\&P1500 boards - leaves a much sparser network in which the results in the tables are not robust. Redefining "powerful" independent directors to include only the top $10 \%, 5 \%$ or $1 \%$ of the power centrality measures distributions in this sparser network does not restore the results. Our power measure, a composite of four power centrality measures using a denser and larger network of historical and current links to the boards of S\&P 1500 and smaller firms, thus appears to proxy for something different from busyness.

\section{A4. Alternative regression specifications}

How we estimate Tobin's Q does not drive the results in Tables 4 and 5. These take Q as the book value of total assets plus the market value of common shares minus the book values of equity and deferred taxes, all 
divided by the book value of total assets. Qualitatively similar results ensue recalculating Tobin's Q using as the numerator the sum of the market value of common shares, book value of short-term and long-term debts, liquidation value of preferred shares, and deferred taxes and investment tax credit, while using the same denominator, total book assets.

Dropping the continuous control variables in Tables 4 and 5 to retain only the year and industry fixed-effects generates qualitatively similar results, except that a powerful CEO becomes significantly associated with higher Qs. Restoring the controls one-by-one reveals R\&D spending critical in rendering CEO power insignificant. R\&D intensive firms have both unusually high $\mathrm{Q}$ and unusually powerful CEOs; and including both leaves R\&D significant and CEO power insignificant. Powerful CEOs have a higher median age, but dropping or including the CEO age does not qualitatively change the results.

\section{A5. Powerful nonindependent Directors and Panel Granger Causality Tests}

Appendix Table A4 presents regressions analogous to Table 5. Table 5 shows that a director other than the CEO chairing the board is unrelated to the firm's Q, and Table A4 shows a powerful independent director as chair is also unrelated to Q. However, a powerful nonindependent director as chair dummy, a powerful nonindependent board dummy (one if a majority of nonindependent directors are powerful) or average nonindependent director power (analogous to $I D C$ ) attracts a significant positive coefficient explaining Q. Including independent and nonindependent director power measures in the same regressions generates qualitatively similar results to those in the tables for the former, but the latter remain significantly positive.

These regressions associating powerful nonindependent chairs and directors with higher Q ratios are not inconsistent their sudden deaths significantly increasing those valuations. However, Granger causality tests, an alternative approach to assessing causality developed for time series and adapted for panel data (Hurlin 2005; Dumitrescu and Hurlin 2012; Lopez and Weber 2017; Elliott, and Golub 2019) indicate reverse causality: higher valuations attract powerful nonindependent directors. A variable $\mathrm{X}$ Granger-causes a variable $Y$ if lagged values of $X$ jointly significantly explain $Y$ in regressions controlling for lagged values of $Y$. Appendix Table A5, using up to three lags, shows independent director power (either $P I B$ or $I D C$ ) Granger-causing $Q ; Q$ not Granger-causing independent director power; nonindependent director and nonindependent chair power not Granger-causing Q; and Q Granger-causing nonindependent director and nonindependent chair power. These tests affirm that powerful independent directors and boards cause higher share valuations; but suggest reverse causality (q attracts powerful nonindependent directors and chairs) drives the results in Table A4. The positive coefficients on powerful nonindependent chairs, powerful nonindependent boards and nonindependent director power are thus consistent with share price increases on the sudden deaths of such directors.

\section{A6. Event Study Robustness Checks}


The director sudden death event study results are highly robust. Panel A of Table 6 uses value-weighted market returns to estimate CARs. Using equal-weighted market returns instead generates qualitatively similar results. Table 6 includes the sudden deaths of old directors which, if expected, might move share prices little. Appendix Table A6 shows that dropping 45 sudden deaths of directors aged over 75 and 82 of director aged over 70 generate results qualitatively similar to Table 6, with only a few exceptions. Specifically, the point estimates in analogs to the leftmost three columns of Panel A, on the sudden deaths of legally independent versus nonindependent director without regard to power, are unstable. Elsewhere, p-levels switch back and forth between significance $(p<0.10)$ and marginal (one-tailed) significance $(p / 2<0.10)$, but signs are preserved and point estimates change little. Director suicides would be endogenous if caused by foreknowledge of poor corporate performance, so Table 6 excludes suicides. Including the four suicides we uncovered generates qualitatively similar results to those in the table. The sudden deaths include no murders, but some might go unreported. ${ }^{13}$

\section{A7. Table 7 Additional Discussion}

Appendix Table A7 shows that continuous independent director power, $I D C$, rather than the powerful independent board dummy, $P I B$, generates results qualitatively similar to Table 7. Expanding the lists of control variables to include all those in Tables 4 and 5 generates qualitatively similar results, as does including dummies or continuous power measures for powerful nonindependent directors, powerful CEOs, powerful independent chairs, and powerful nonindependent non-CEO chairs.

A few exceptions merit mention. Regressions 7A.1 and 7A.2, which explain bidder CAR and bidder and target combined CAR on M\&A announcements with the powerful independent board dummy, $P I B$, control for CEO power, $P C E O$, because El-Khatib et al. (2015) associate powerful CEOs with valuedestroying M\&A. These are the only results in the tables where CEO power is significant, and they are not robust to omitting this variable. Regressions 7A.3 and 7A.4 drop CEO successions if the departing CEO is over 60 to exclude normal retirements and ensure an outsider successor reliably indicates a forced turnover. Using 65 , rather than 60 , renders independent director power insignificant, as does using all CEO turnovers regardless of outgoing CEO age.

\section{A8. CEO Pay regressions}

Appendix table A8 presents the CEO pay regressions described at the end of section 4.

${ }^{13} \mathrm{We}$ are grateful to an anonymous referee for suggesting this possibility. 


\section{Appendix Table A1. Top Executive and Director Network Characteristics}

Each Node is a director or business executive with at least one connection to other directors or executives. The network includes all directors and senior managers who ever served on the board of or worked at a firm covered by BoardEx from 1998 through 2009.

\begin{tabular}{ccc} 
Year & $\begin{array}{c}\text { Nodes (Individuals) in } \\
\text { Social Network }\end{array}$ & $\begin{array}{c}\text { Connections between pairs of } \\
\text { Nodes (Individuals) in Social } \\
\text { Network }\end{array}$ \\
\hline 1998 & 191,049 & $5,438,006$ \\
1999 & 200,156 & $5,925,380$ \\
2000 & 210,220 & $6,483,455$ \\
2001 & 219,321 & $6,991,534$ \\
2002 & 228,375 & $7,466,223$ \\
2003 & 237,980 & $7,967,959$ \\
2005 & 249,126 & $8,511,737$ \\
2006 & 261,823 & $9,105,517$ \\
2007 & 276,237 & $9,757,497$ \\
2008 & 292,131 & $10,472,468$ \\
2009 & 305,399 & $11,156,481$ \\
& 313,958 & $11,639,006$ \\
\hline
\end{tabular}




\section{Appendix Table A2: Definitions of Additional Variables in Appendix Tests}

Variable

Definition

\begin{tabular}{cl}
\hline Measures of Director Independence and Power & \\
Powerful Nonindependent Director (PNID) & $\begin{array}{l}\text { Firm-dependent director-level dummy set to } 1 \text { if director is both powerful (PD = 1) and listed } \\
\text { as a nonindependent in the proxy, } 0 \text { otherwise }\end{array}$ \\
Powerful Nonindependent Board (PNIB) & $\begin{array}{l}\text { Annual firm-level dummy set to } 1 \text { if a majority of nonindependent directors are powerful, } 0 \\
\text { otherwise }\end{array}$ \\
Nonindependent Director Centrality (NIDC) & $\begin{array}{l}\text { Annual firm-level mean of individual-level means of each nonindependent director's highest } \\
3 \text { centrality measures }\end{array}$
\end{tabular}

Measures of Chair Independence and Power

Powerful Independent Non-CEO Chair (PINC)

Powerful Nonindependent Non-CEO Chair (PNINC)

Independent Non-CEO Chair Centrality (INCC)

Nonindependent Non-CEO Chair Centrality (NINCC)

Annual firm-level dummy set to 1 if chair is powerful independent director (PID = 1), 0 otherwise

Annual firm-level dummy set to 1 if chair is powerful nonindependent director (PNID = 1) and not $\mathrm{CEO}, 0$ otherwise

Annual firm-level variable equal to mean of chair's highest 3 percentile centrality measures if chair is an independent director, 0 otherwise

Annual firm-level variable equal to mean of chair's highest 3 centrality measures if chair is nonindependent director other than $\mathrm{CEO}, 0$ otherwise

\section{Measures of Independent Directors' Power in Specific Decisions}

Powerful Independent Compensation Committee (PIBC)

Dummy set to 1 if majority compensation committee are powerful independent directors, 0 otherwise

Centrality of Nominating Comm. Members (IDCN)

Mean of the top 3 centrality measures for independent directors on nominating committee

Centrality of Auditing Comm. Members (IDCA)

Mean of the top 3 centrality measures for independent directors on auditing committee

Centrality of Compensation Comm. Members (IDCC)

Mean of the top 3 centrality measures for independent directors on compensation committee 


\section{Appendix Table A3. Firm-level Variable Summary Statistics}

Summary statistics of variables in Table 2 and Appendix A2. Sample is 15,889 firm-year observations.

\begin{tabular}{|c|c|c|c|c|c|c|}
\hline & & Mean & $\begin{array}{l}\text { Standard } \\
\text { deviation }\end{array}$ & Q1 & Median & Q3 \\
\hline Independent board & $I B$ & 0.914 & 0.281 & 1 & 1 & 1 \\
\hline Powerful independent board & $P I B$ & 0.523 & 0.499 & 0 & 1 & 1 \\
\hline Powerful nonindependent board & $P N I B$ & 0.313 & 0.464 & 0 & 0 & 1 \\
\hline Independent director centrality & $I D C$ & 81.1 & 14.9 & 74.3 & 84.9 & 92.1 \\
\hline Nonindependent director centrality & $N I D C$ & 55.1 & 35.8 & 0 & 66.8 & 85.3 \\
\hline Non-CEO chair & NCC & 0.358 & 0.479 & 0 & 0 & 1 \\
\hline Powerful non-CEO chair & $P N C$ & 0.214 & 0.410 & 0 & 0 & 0 \\
\hline Powerful independent non-CEO chair & PINC & 0.111 & 0.314 & 0 & 0 & 0 \\
\hline Powerful nonindependent non-CEO chair & PNINC & 0.103 & 0.304 & 0 & 0 & 0 \\
\hline Non-CEO chair centrality & NCCC & 28.5 & 39.7 & 0 & 0 & 74 \\
\hline Independent non-CEO chair centrality & INCC & 13.0 & 31.1 & 0 & 0 & 0 \\
\hline Nonindependent non-CEO chair centrality & NINCC & 15.5 & 31.8 & 0 & 0 & 0 \\
\hline Powerful CEO & PCEO & 0.464 & 0.499 & 0 & 0 & 1 \\
\hline CEO centrality & CEOC & 77.3 & 19.2 & 65.3 & 82.3 & 93 \\
\hline Powerful independent auditing committee & PIBA & 0.490 & 0.500 & 0 & 0 & 1 \\
\hline Powerful independent compensation committee & $P I B C$ & 0.520 & 0.500 & 0 & 1 & 1 \\
\hline Powerful independent nominating committee & $P I B N$ & 0.442 & 0.497 & 0 & 0 & 1 \\
\hline Auditing committee members centrality & $I D C A$ & 80.7 & 16.3 & 73.3 & 85.0 & 92.8 \\
\hline Compensation committee members centrality & $I D C C$ & 80.9 & 18.1 & 74.0 & 86.2 & 93.6 \\
\hline Nominating committee members centrality & $I D C N$ & 70.7 & 32.0 & 64.0 & 83.8 & 92.8 \\
\hline Tobin's Q & $Q$ & 1.58 & 1.55 & 0.848 & 1.19 & 1.83 \\
\hline CEO Age & CEOA & 55.7 & 7.33 & 51 & 56 & 60 \\
\hline Board Size & BSIZE & 9.44 & 2.62 & 8 & 9 & 11 \\
\hline E-Index & $E N D X$ & 2.72 & 1.4 & 2 & 3 & 4 \\
\hline Total Assets (in \$bil.) & ASSETS & 16.8 & 89.2 & 0.755 & 2.12 & 7.37 \\
\hline Leverage & $L E V$ & 0.225 & 0.181 & 0.066 & 0.212 & 0.339 \\
\hline Profitability & PROFIT & 0.126 & 0.101 & 0.07 & 0.121 & 0.176 \\
\hline Capital expenditure & CAPEX & 0.049 & 0.062 & 0.013 & 0.0324 & 0.0638 \\
\hline Cash flow & $C F$ & 0.0908 & 0.125 & 0.0407 & 0.0878 & 0.142 \\
\hline R\&d & $R \& D$ & 0.024 & 0.0444 & 0 & 0 & 0.0279 \\
\hline Advertising & $A D V$ & 0.0102 & 0.0245 & 0 & 0 & 0.00584 \\
\hline Earnings manipulation & $E M$ & 0.00819 & 0.0870 & -0.0228 & 0.0113 & 0.0464 \\
\hline
\end{tabular}


Appendix Table A4. Powerful Independent Directors versus Powerful Nonindependent Directors

OLS regressions explain Tobin's Q (Q) with measures of directors' independent director power vs nonindependent director power, as well as all control variables from Table 4 and industry and year fixedeffects (not shown). Variables are as described in Table 2. Sample is a 13,933 firm-year panel of S\&P 1500 firms from 1999 to 2010. Numbers in parentheses are robust p-levels clustering by firm. Boldface denotes significance at $10 \%$ or better.

\begin{tabular}{|c|c|c|c|c|c|c|c|}
\hline Regression & A4.1 & A4.2 & A4.3 & A4.4 & A4.5 & A4.6 & A4.7 \\
\hline $\begin{array}{l}\text { Powerful independent non- } \\
\text { CEO chair (PINC) }\end{array}$ & $\begin{array}{c}-0.0751 \\
(0.13)\end{array}$ & & $\begin{array}{c}-0.0551 \\
(0.28)\end{array}$ & & & $\begin{array}{c}-0.0637 \\
(0.21)\end{array}$ & $\begin{array}{c}-0.0636 \\
(0.21)\end{array}$ \\
\hline $\begin{array}{l}\text { Powerful nonindependent non- } \\
\text { CEO chair (PNINC) }\end{array}$ & & $\begin{array}{l}0.160 \\
(0.00)\end{array}$ & $\begin{array}{l}0.153 \\
(0.00)\end{array}$ & & & $\begin{array}{l}0.124 \\
(0.01)\end{array}$ & $\begin{array}{l}0.126 \\
(0.01)\end{array}$ \\
\hline $\begin{array}{l}\text { Powerful nonindependent } \\
\text { board dummy (PNIB) }\end{array}$ & & & & $\begin{array}{c}0.0951 \\
(0.00)\end{array}$ & $\begin{array}{c}0.0873 \\
(0.00)\end{array}$ & $\begin{array}{c}0.0588 \\
(0.06)\end{array}$ & $\begin{array}{c}0.0566 \\
(0.08)\end{array}$ \\
\hline $\begin{array}{c}\text { Powerful independent board } \\
\text { dummy }(P I B)\end{array}$ & & & & & $\begin{array}{c}0.0530 \\
(0.10)\end{array}$ & $\begin{array}{c}0.0592 \\
(0.06)\end{array}$ & $\begin{array}{c}0.0554 \\
(0.09)\end{array}$ \\
\hline Powerful CEO dummy (PCEO) & & & & & & & $\begin{array}{c}0.0163 \\
(0.63)\end{array}$ \\
\hline Control variables & $\mathrm{Y}$ & $\mathrm{Y}$ & Y & Y & Y & Y & Y \\
\hline Industry fixed-effects & $\mathrm{Y}$ & $\mathrm{Y}$ & Y & $\mathrm{Y}$ & Y & $\mathrm{Y}$ & $\mathrm{Y}$ \\
\hline Year fixed-effects & Y & Y & $\mathrm{Y}$ & $\mathrm{Y}$ & $\mathrm{Y}$ & $\mathrm{Y}$ & $\mathrm{Y}$ \\
\hline Adjusted R-squared & 0.388 & 0.389 & 0.389 & 0.389 & 0.389 & 0.390 & 0.390 \\
\hline
\end{tabular}




\section{Appendix Table A5: Granger Causality Tests}

The left panel runs regressions of Tobin's Q on lags of Q and lags of X; the right panel runs X on lags of $\mathrm{Q}$ and lags of $\mathrm{X}$. In the first and second rows, $\mathrm{X}$ is PIB (a powerful independent board dummy) and the continuous variables IDC (mean independent director power centrality), respectively. In the remaining rows, $\mathrm{X}$ is one of PNIB (one if a majority of nonindependent director are powerful), PINC (one if the chair is a powerful independent director), or PNINC (one if the chair is a powerful nonindependent director) or one of NIDC (mean nonindependent director centrality), INCC (chair's power centrality if an independent director is chair), or NINCC (chair's power centrality if a nonindependent director other than the CEO is chair). Regressions explaining Q are OLS; those explaining $\mathrm{X}$ are probits if $\mathrm{X}$ is an indicator variable (PIB, PNIB, PINC, or PNINC) and OLS if $\mathrm{X}$ is continuous (IDC, NIDC, INCC, or NINCC). Numbers in parentheses are $\mathrm{p}$-levels for t-tests (one lag specifications) or joint F-tests (two and three lag specifications) for rejecting the insignificance or joint insignificance of all included lags of X (left panel) or Q (right panel).

\begin{tabular}{|c|c|c|c|c|c|c|}
\hline \multirow{3}{*}{$\begin{array}{c}\text { Power } \\
\text { measure } \\
\left(X_{i, t}\right) \text { is: }\end{array}$} & \multicolumn{3}{|c|}{$\begin{array}{c}\text { Board power Granger causes shareholder } \\
\text { value }\end{array}$} & \multicolumn{3}{|c|}{$\begin{array}{c}\text { Shareholder value Granger causes board } \\
\text { power }\end{array}$} \\
\hline & $Q_{i, t}=\sum$ & $\begin{array}{l}Q_{i, t-s}+ \\
+u_{i, t}\end{array}$ & $b_{s} X_{i, t-s}$ & $X_{i, t}=$ & $\begin{array}{c}{ }_{s} X_{i, t-s}+ \\
+u_{i, t}\end{array}$ & $b_{s} Q_{i, t-s}$ \\
\hline & 1 lag & 2 lags & 3 lags & $1 \operatorname{lag}$ & 2 lags & 3 lags \\
\hline$P I B$ & $\begin{array}{c}3.24 \\
(0.07)\end{array}$ & $\begin{array}{c}4.84 \\
(0.01)\end{array}$ & $\begin{array}{c}3.43 \\
(0.02)\end{array}$ & $\begin{array}{c}2.64 \\
(0.11)\end{array}$ & $\begin{array}{c}4.59 \\
(0.10)\end{array}$ & $\begin{array}{l}17.82 \\
(0.00)\end{array}$ \\
\hline$I D C$ & $\begin{array}{c}4.33 \\
(0.04)\end{array}$ & $\begin{array}{c}3.97 \\
(0.02)\end{array}$ & $\begin{array}{c}4.99 \\
(0.00)\end{array}$ & $\begin{array}{c}2.05 \\
(0.15)\end{array}$ & $\begin{array}{c}1.36 \\
(0.26)\end{array}$ & $\begin{array}{c}1.16 \\
(0.32)\end{array}$ \\
\hline PNIB & $\begin{array}{c}0.38 \\
(0.54)\end{array}$ & $\begin{array}{c}0.91 \\
(0.40)\end{array}$ & $\begin{array}{c}1.00 \\
(0.39)\end{array}$ & $\begin{array}{l}10.69 \\
(0.00)\end{array}$ & $\begin{array}{c}8.30 \\
(0.02)\end{array}$ & $\begin{array}{l}17.12 \\
(0.00)\end{array}$ \\
\hline PINC & $\begin{array}{l}2.08 \\
(0.15)\end{array}$ & $\begin{array}{c}2.00 \\
(0.14)\end{array}$ & $\begin{array}{c}0.23 \\
(0.88)\end{array}$ & $\begin{array}{c}6.48 \\
(0.01)\end{array}$ & $\begin{array}{l}10.35 \\
(0.01)\end{array}$ & $\begin{array}{c}5.17 \\
(0.16)\end{array}$ \\
\hline PNINC & $\begin{array}{c}1.87 \\
(0.17)\end{array}$ & $\begin{array}{c}1.13 \\
(0.32)\end{array}$ & $\begin{array}{c}0.37 \\
(0.78)\end{array}$ & $\begin{array}{c}7.89 \\
(0.01)\end{array}$ & $\begin{array}{l}10.39 \\
(0.01)\end{array}$ & $\begin{array}{c}9.79 \\
(0.02)\end{array}$ \\
\hline NIDC & $\begin{array}{c}0.07 \\
(0.79)\end{array}$ & $\begin{array}{c}0.62 \\
(0.54)\end{array}$ & $\begin{array}{c}2.1 \\
(0.10)\end{array}$ & $\begin{array}{l}15.49 \\
(0.00)\end{array}$ & $\begin{array}{c}3.81 \\
(0.02)\end{array}$ & $\begin{array}{c}6.60 \\
(0.00)\end{array}$ \\
\hline NINCC & $\begin{array}{l}3.76 \\
(0.05)\end{array}$ & $\begin{array}{c}0.96 \\
(0.38)\end{array}$ & $\begin{array}{c}0.69 \\
(0.56)\end{array}$ & $\begin{array}{l}10.81 \\
(0.00)\end{array}$ & $\begin{array}{l}10.43 \\
(0.00)\end{array}$ & $\begin{array}{c}3.91 \\
(0.01)\end{array}$ \\
\hline
\end{tabular}




\section{Appendix Table 6: Abnormal Returns on Powerful Independent Director Sudden Deaths}

The tests in panel A of Table 6 drop suicides and include deaths at all ages. These rerun Table 6 dropping deaths of directors aged over 75 and over 70 and including suicides. Cumulative abnormal returns (CARs), in percent, for windows $[-1,1],[-1,2],[-1,3]$, and $[-3,3]$, with $t=0$ the first news of the director's sudden death and $\left[\mathrm{t}_{1}, \mathrm{t}_{2}\right]$ a window from $\mathrm{t}_{1}$ to $\mathrm{t}_{2}$. CARs are actual returns less market model estimates, parameters estimated using $\mathrm{t}=-200$ to -46 , using the CRSP value-weighted total market return (Panel A1) and both the equal- and value-weighted CRSP total market return (Panel A2). Numbers in parenthesis are p-values for t-tests. Boldface indicates significance at $10 \%$ or better. Tests reject equal means in Panel A and zero coefficients in Panel B.

Panel A: Mean cumulative abnormal returns on news of director sudden deaths

Decedents: All directors Independent directors Non-independent directors

Test: Decedent is independent? Decedent is powerful? Decedent is powerful?

\begin{tabular}{c|ccc|cccc|ccc|} 
Window & Yes & No & Difference & \multicolumn{2}{c}{ Yes } & No & Difference & Yes & No & Difference \\
\hline A1. Sample as in Table 6 Panel & A but dropping 45 & deaths of directors aged over & $\mathbf{7 5}$ & $(\boldsymbol{N}=\mathbf{1 7 7})$ & \\
\hline$[-1,+1]$ & -0.066 & -0.25 & 0.184 & $\mathbf{- 0 . 3 7 8}$ & 0.469 & $\mathbf{- 0 . 8 4 7}$ & $\mathbf{0 . 6 3 5}$ & -0.488 & 1.12 \\
& $(0.25)$ & $(0.37)$ & $(0.39)$ & $\mathbf{( 0 . 0 6 )}$ & $(0.18)$ & $\mathbf{( 0 . 0 8 )}$ & $\mathbf{( 0 . 1 0 )}$ & $(0.15)$ & $(0.20)$ \\
{$[-1,+2]$} & 0.118 & -0.818 & $\mathbf{0 . 9 3 6}$ & -0.275 & $\mathbf{0 . 7 9 2}$ & $\mathbf{- 1 . 0 6 7}$ & $\mathbf{0 . 8 9}$ & $\mathbf{- 1 . 2 8}$ & $\mathbf{2 . 1 7}$ \\
& $(0.46)$ & $(0.23)$ & $\mathbf{( 0 . 1 0 )}$ & $(0.13)$ & $\mathbf{( 0 . 0 9 )}$ & $\mathbf{( 0 . 0 5 )}$ & $\mathbf{( 0 . 0 6 )}$ & $\mathbf{( 0 . 0 5 )}$ & $\mathbf{( 0 . 1 1 )}$ \\
{$[-1,+3]$} & 0.19 & -0.831 & 1.021 & -0.237 & $\mathbf{0 . 9 2 5}$ & $\mathbf{- 1 . 1 6 2}$ & $\mathbf{1 . 0 9}$ & $\mathbf{- 1 . 3 5}$ & $\mathbf{2 . 4 4}$ \\
& $(0.41)$ & $(0.27)$ & $(0.12)$ & $(0.20)$ & $\mathbf{( 0 . 0 7 )}$ & $\mathbf{( 0 . 0 7 )}$ & $\mathbf{( 0 . 0 9 )}$ & $\mathbf{( 0 . 0 8 )}$ & $\mathbf{( 0 . 0 6 )}$ \\
{$[-3,+3]$} & 0.126 & -1.11 & $\mathbf{1 . 2 3 6}$ & -0.252 & 0.775 & -1.027 & $\mathbf{1 . 4 5}$ & $\mathbf{- 1 . 8}$ & $\mathbf{3 . 2 5}$ \\
& $(0.46)$ & $(0.21)$ & $\mathbf{( 0 . 1 0 )}$ & $(0.22)$ & $(0.20)$ & $(0.13)$ & $\mathbf{( 0 . 0 6 )}$ & $\mathbf{( 0 . 0 4 )}$ & $\mathbf{( 0 . 0 5 )}$ \\
\hline Events & 144 & 33 & 177 & 91 & 53 & 144 & 7 & 26 & 33
\end{tabular}

A2. Sample as in Table 6 Panel A but dropping 82 deaths of directors aged over $70(N=140)$

\begin{tabular}{c|ccc|ccc|ccc}
\hline $\mathbf{- 1},+\mathbf{1}]$ & 0.0283 & $\mathbf{- 0 . 2 9 1}$ & 0.319 & -0.266 & 0.525 & -0.791 & 0.273 & -0.419 & 0.69 \\
& $(0.37)$ & $\mathbf{( 0 . 2 2 )}$ & $(0.34)$ & $(0.14)$ & $(0.20)$ & $(0.14)$ & $(0.38)$ & $(0.16)$ & $(0.33)$ \\
{$[-\mathbf{- 1},+\mathbf{2}]$} & 0.195 & -0.905 & $\mathbf{1 . 1 0 0}$ & -0.0634 & 0.631 & -0.6944 & 0.50 & $\mathbf{- 1 . 2 3}$ & 1.73 \\
& $(0.46)$ & $(0.13)$ & $\mathbf{( 0 . 0 9 )}$ & $(0.30)$ & $(0.20)$ & $(0.18)$ & $(0.29)$ & $\mathbf{( 0 . 0 6}$ & $(0.20)$ \\
{$[-\mathbf{- 1},+3]$} & 0.323 & -1.04 & $\mathbf{1 . 3 6 3}$ & 0.0833 & 0.729 & -0.6457 & 0.879 & $\mathbf{- 1 . 4 8}$ & $\mathbf{2 . 3 6}$ \\
& $(0.32)$ & $\mathbf{( 0 . 1 5 )}$ & $\mathbf{( 0 . 0 8 )}$ & $(0.45)$ & $(0.18)$ & $(0.24)$ & $(0.27)$ & $\mathbf{( 0 . 0 7 )}$ & $\mathbf{( 0 . 0 9 )}$ \\
{$[-\mathbf{- 3},+\mathbf{3}]$} & 0.054 & $\mathbf{- 1 . 3 6}$ & $\mathbf{1 . 4 1 4}$ & -0.116 & -0.341 & 0.225 & 0.822 & $\mathbf{- 1 . 8 6}$ & 2.68 \\
& $(0.38)$ & $\mathbf{( 0 . 0 9 )}$ & $\mathbf{( 0 . 1 0 )}$ & $(0.31)$ & $(0.45)$ & $(0.33)$ & $(0.29)$ & $\mathbf{( 0 . 0 4 )}$ & $(0.12)$ \\
\hline Events & 113 & 27 & 140 & 71 & 42 & 113 & 5 & 22 & 27
\end{tabular}

A3. Sample as in Table 6 Panel $A$ but also including 4 deaths by suicide $(N=226)$

\begin{tabular}{c|ccc|ccc|ccc}
\hline$[-\mathbf{1},+\mathbf{1}]$ & -0.0197 & $\mathbf{0 . 6 1 8}$ & -0.638 & -0.311 & 0.394 & $\mathbf{- 0 . 7 0 5}$ & $\mathbf{1 . 6 5}$ & 0.322 & 1.33 \\
& $(0.29)$ & $\mathbf{( 0 . 0 9 )}$ & $(0.12)$ & $(0.24)$ & $(0.17)$ & $\mathbf{( 0 . 0 9 )}$ & $\mathbf{( 0 . 0 2 )}$ & $(0.34)$ & $(0.12)$ \\
{$[-\mathbf{- 1},+\mathbf{2}]$} & 0.0602 & 0.219 & -0.159 & -0.251 & 0.503 & $\mathbf{- 0 . 7 5 4}$ & $\mathbf{1 . 6 0}$ & -0.177 & $\mathbf{1 . 7 8}$ \\
& $(0.41)$ & $(0.24)$ & $(0.40)$ & $(0.29)$ & $(0.16)$ & $\mathbf{( 0 . 1 0 )}$ & $\mathbf{( 0 . 0 2 )}$ & $(0.39)$ & $\mathbf{( 0 . 0 8 )}$ \\
{$[-\mathbf{- 1},+3]$} & 0.0247 & 0.158 & -0.1333 & -0.252 & 0.419 & -0.671 & $\mathbf{1 . 8 6}$ & -0.329 & $\mathbf{2 . 1 9}$ \\
& $(0.41)$ & $(0.26)$ & $(0.42)$ & $(0.37)$ & $(0.22)$ & $(0.18)$ & $\mathbf{( 0 . 0 3 )}$ & $(0.40)$ & $\mathbf{( 0 . 0 1 )}$ \\
{$[-3,+3]$} & -0.209 & 0.165 & -0.374 & -0.332 & -0.0336 & -0.2984 & $\mathbf{1 . 9 5}$ & -0.346 & $\mathbf{2 . 3 0}$ \\
& $(0.17)$ & $(0.25)$ & $(0.32)$ & $(0.44)$ & $(0.40)$ & $(0.36)$ & $\mathbf{( 0 . 0 3 )}$ & $(0.40)$ & $\mathbf{( 0 . 0 2 )}$ \\
\hline Events & 172 & 54 & 226 & 101 & 71 & 172 & 12 & 42 & 54
\end{tabular}




\section{Panel B: OLS Regressions of CARs on decedent director independence and power indicators}

Regressions explain CARs of various lengths around director sudden deaths with dummies for decedent director being powerful, legally independent or both, as well as controls for director age at death and firm characteristics, as in Panel B of Table 6. CARs are estimated using equal-weighted market returns (columns 1 to 4 ) or value-weighted market returns (columns 5 to 8 )

Market return weights equal equal equal equal Value value value value Event window $\quad[-1,+1] \quad[-1,+2] \quad[-1,+3] \quad[-3,+3] \quad[-1,+1] \quad[-1,+2] \quad[-1,+3] \quad[-3,+3]$

B1. Sample as in Table 6 but dropping 45 deaths of directors aged over 75 ( $N=177)$

\begin{tabular}{|c|c|c|c|c|c|c|c|c|}
\hline Regression & 6B1.1 & 6B1.2 & $6 B 1.3$ & 6B1.4 & 6B1.5 & 6B1.6 & 6B1.7 & $6 B 1.8$ \\
\hline $\begin{array}{l}\text { Powerful director } \\
(P D)\end{array}$ & $\begin{array}{c}1.65 \\
(0.33)\end{array}$ & $\begin{array}{c}4.07 \\
(0.04)\end{array}$ & $\begin{array}{c}3.50 \\
(0.07)\end{array}$ & $\begin{array}{c}4.94 \\
(0.02)\end{array}$ & $\begin{array}{c}0.57 \\
(0.75)\end{array}$ & $\begin{array}{c}2.43 \\
(0.23)\end{array}$ & $\begin{array}{c}1.69 \\
(0.40)\end{array}$ & $\begin{array}{c}3.11 \\
(0.17)\end{array}$ \\
\hline $\begin{array}{c}\text { Independent director } \\
\text { (ID) }\end{array}$ & $\begin{array}{c}1.31 \\
(0.24)\end{array}$ & $\begin{array}{c}2.65 \\
(\mathbf{0 . 0 3})\end{array}$ & $\begin{array}{c}3.57 \\
(\mathbf{0 . 0 0 )}\end{array}$ & $\begin{array}{c}3.91 \\
(0.00)\end{array}$ & $\begin{array}{c}0.80 \\
(0.47)\end{array}$ & $\begin{array}{c}2.00 \\
(0.10)\end{array}$ & $\begin{array}{c}2.86 \\
(0.01)\end{array}$ & $\begin{array}{c}3.06 \\
(\mathbf{0 . 0 1})\end{array}$ \\
\hline $\begin{array}{l}\text { Powerful independent } \\
\text { director (PID) }\end{array}$ & $\begin{array}{l}-3.14 \\
(0.11)\end{array}$ & $\begin{array}{l}-6.29 \\
0.00\end{array}$ & $\begin{array}{c}-6.44 \\
0.00\end{array}$ & $\begin{array}{c}-7.99 \\
0.00\end{array}$ & $\begin{array}{l}-1.83 \\
(0.36)\end{array}$ & $\begin{array}{l}-4.33 \\
(0.05)\end{array}$ & $\begin{array}{l}-4.32 \\
(0.05)\end{array}$ & $\begin{array}{l}-5.65 \\
(0.03)\end{array}$ \\
\hline $\mathrm{N}$ & 0.129 & 0.267 & 0.282 & 0.309 & 0.124 & 0.245 & 0.266 & 0.271 \\
\hline
\end{tabular}

B2. Sample as in Table 6 but dropping 82 deaths of directors aged over $70(N=140)$

\begin{tabular}{ccccccccc}
\hline Regression & $\mathbf{6 B 2 . 1}$ & $\mathbf{6 B 2 . 2}$ & $\mathbf{6 B 2} .3$ & $\mathbf{6 B 2 . 4}$ & $\mathbf{6 B 2 . 5}$ & $\mathbf{6 B 2 . 6}$ & $\mathbf{6 B 2 . 7}$ & $\mathbf{6 B 2 . 8}$ \\
\hline $\begin{array}{c}\text { Powerful director } \\
(P D)\end{array}$ & 1.22 & $\mathbf{4 . 0 7}$ & 3.73 & $\mathbf{4 . 9 3}$ & 0.91 & 3.33 & 3.08 & $\mathbf{4 . 3 3}$ \\
$(0.58)$ & $\mathbf{( 0 . 0 9 )}$ & $(0.16)$ & $\mathbf{( 0 . 0 8 )}$ & $(0.66)$ & $(0.14)$ & $(0.22)$ & $\mathbf{( 0 . 1 0 )}$ \\
$\begin{array}{c}\text { Independent director } \\
(I D)\end{array}$ & 1.45 & $\mathbf{2 . 3 0}$ & $\mathbf{3 . 6 7}$ & $\mathbf{3 . 8 3}$ & 1.13 & 1.70 & $\mathbf{2 . 9 2}$ & $\mathbf{2 . 9 1}$ \\
$\begin{array}{c}(0.32) \\
\mathbf{( 0 . 1 0 )}\end{array}$ & $\mathbf{( 0 . 0 1 )}$ & $\mathbf{( 0 . 0 2 )}$ & $(0.42)$ & $(0.21)$ & $\mathbf{( 0 . 0 4 )}$ & $\mathbf{( 0 . 0 5 )}$ \\
$\begin{array}{c}\text { Powerful independent } \\
\text { director }(\boldsymbol{P I D})\end{array}$ & -2.53 & $\mathbf{- 5 . 6 2}$ & $\mathbf{- 5 . 8 9}$ & $\mathbf{- 7 . 0 8}$ & -2.22 & $\mathbf{- 4 . 8 3}$ & $\mathbf{- 5 . 1 6}$ & $\mathbf{- 6 . 2 6}$ \\
\hline $\mathbf{R}^{2}$ & $(0.36)$ & $\mathbf{( 0 . 0 4 )}$ & $\mathbf{( 0 . 0 4 )}$ & $\mathbf{( 0 . 0 3 )}$ & $(0.40)$ & $\mathbf{( 0 . 0 6 )}$ & $\mathbf{( 0 . 0 7 )}$ & $\mathbf{( 0 . 0 5 )}$ \\
\hline
\end{tabular}

B3. Sample as in Table 6 but also including 4 deaths by suicide $(N=226)$

\begin{tabular}{cccccccccc}
\hline Regression & $\mathbf{6 B 3 . 1}$ & $\mathbf{6 B 3 . 2}$ & $\mathbf{6 B 3 . 3}$ & $\mathbf{6 B 3 . 4}$ & $\mathbf{6 B 3 . 5}$ & $\mathbf{6 B 3 . 6}$ & $\mathbf{6 B 3 . 7}$ & $\mathbf{6 B 3 . 8}$ \\
\hline $\begin{array}{c}\text { Powerful director } \\
(\boldsymbol{P D})\end{array}$ & 1.68 & $\mathbf{2 . 3 1}$ & $\mathbf{2 . 8 8}$ & $\mathbf{2 . 8 9}$ & 1.33 & 1.78 & 2.19 & 1.97 \\
& $(0.14)$ & $\mathbf{( 0 . 0 6 )}$ & $\mathbf{( 0 . 0 5 )}$ & $\mathbf{( 0 . 1 0 )}$ & $(0.23)$ & $(0.16)$ & $(0.14)$ & $(0.17)$ \\
$\begin{array}{c}\text { Independent director } \\
(I D)\end{array}$ & 0.19 & 0.74 & 0.87 & 0.44 & 0.07 & 0.68 & 0.75 & 0.71 \\
$\begin{array}{c}(0.78) \\
(0.31)\end{array}$ & $(0.32)$ & $(0.68)$ & $(0.91)$ & $(0.36)$ & $(0.39)$ & $(0.40)$ \\
$\begin{array}{c}\text { Powerful independent } \\
\text { director }(\boldsymbol{P I D})\end{array}$ & $\mathbf{- 2 . 3 9}$ & $\mathbf{- 2 . 9 9}$ & $\mathbf{- 3 . 4 2}$ & $\mathbf{- 3 . 2 2}$ & $\mathbf{- 2 . 0 4}$ & $\mathbf{- 2 . 5 4}$ & $\mathbf{- 2 . 8 6}$ & -2.33 \\
\hline $\mathbf{R}^{\mathbf{( 0 . 0 6}}$ & $\mathbf{( 0 . 0 3 )}$ & $\mathbf{( 0 . 0 3 )}$ & $\mathbf{( 0 . 1 0 )}$ & $\mathbf{( 0 . 1 0 )}$ & $\mathbf{( 0 . 0 7 )}$ & $\mathbf{( 0 . 0 8 )}$ & $(0.14)$ \\
\hline & 0.125 & 0.22 & 0.237 & 0.251 & 0.106 & 0.176 & 0.192 & 0.195
\end{tabular}




\section{Appendix A7: Channels of Value Addition by Powerful Independent Boards}

This table reports Table 7 robustness checks substituting continuous power measures for dummies.

\section{Panel A: Value Destroying M\&A and CEO turnover}

OLS regressions A7A.1 and A7A.2 explain cumulative abnormal returns from day -3 to day +3 around S\&P500 firms' M\&A announcement dates in 1999 through 2010 using continuous independent director $(I D C)$ and continuous CEO (CEOC) power measures, control variables, and industry and year fixed-effects. Binomial probit regressions A7A.3 and A7A.4 explain log odds of a forced CEO turnover using continuous independent director $(I D C)$ or continuous independent directors on nominating committee $(I D C N)$ power measure and interactions with prior year total stock return (RET), control variables, and industry and year fixed-effects. Forced CEO turnover dummy is 1 if a new CEO from outside the firm is appointed that year and 0 otherwise for 212 forced and 394 non-forced CEO turnovers in 1999 to 2010. Numbers in parentheses are robust p-levels clustering by firm. Boldface denotes significance at $10 \%$ or better.

\begin{tabular}{|c|c|c|c|c|}
\hline \multirow{3}{*}{$\begin{array}{c}\text { Regression } \\
\text { Explained variable } \\
\text { CAR is for } \\
\text { Ind. Director power measure }\end{array}$} & A7A.1 & A7A.2 & A7A.3 & A7A.4 \\
\hline & \multicolumn{2}{|c|}{ CAR $[-3,+3]$} & \multicolumn{2}{|c|}{ Forced CEO Turnover } \\
\hline & $\begin{array}{l}\text { Bidder } \\
\text { IDC }\end{array}$ & $\begin{array}{l}\text { Combined } \\
\text { IDC }\end{array}$ & IDC & IDCN \\
\hline Independent director power & $\begin{array}{c}\mathbf{0 . 0 7 7 7} \\
(\mathbf{0 . 0 3})\end{array}$ & $\begin{array}{c}0.0396 \\
(0.26)\end{array}$ & $\begin{array}{c}0.0109 \\
(0.02)\end{array}$ & $\begin{array}{c}0.00237 \\
(0.19)\end{array}$ \\
\hline $\begin{array}{c}\text { Independent director power } \\
\times R E T^{a}\end{array}$ & & & $\begin{array}{c}-0.0112 \\
(0.35)\end{array}$ & $\begin{array}{c}0.00003 \\
(0.99)\end{array}$ \\
\hline$R E T$ & & & $\begin{array}{l}0.669 \\
(0.51)\end{array}$ & $\begin{array}{l}-0.267 \\
(0.22)\end{array}$ \\
\hline CEOC & $\begin{array}{l}-0.127 \\
(0.00)\end{array}$ & $\begin{array}{l}-0.087 \\
(0.00)\end{array}$ & & \\
\hline $\log (C E O$ age $)$ & $\begin{array}{l}6.56 \\
(0.02)\end{array}$ & $\begin{array}{l}2.90 \\
(0.27)\end{array}$ & $\begin{array}{l}-0.46 \\
(0.40)\end{array}$ & $\begin{array}{l}-0.494 \\
(0.36)\end{array}$ \\
\hline Log(board size) & $\begin{array}{c}-0.0736 \\
(0.94)\end{array}$ & $\begin{array}{l}-1.43 \\
(0.17)\end{array}$ & $\begin{array}{l}-0.436 \\
(0.08)\end{array}$ & $\begin{array}{l}-0.356 \\
(0.15)\end{array}$ \\
\hline e-index & $\begin{array}{l}0.223 \\
(0.33)\end{array}$ & $\begin{array}{l}0.276 \\
(0.21)\end{array}$ & $\begin{array}{c}-0.0138 \\
(0.74)\end{array}$ & $\begin{array}{c}-0.0218 \\
(0.60)\end{array}$ \\
\hline Same industry dummy & $\begin{array}{l}-0.359 \\
(0.58)\end{array}$ & $\begin{array}{c}-0.00233 \\
(0.71)\end{array}$ & & \\
\hline Stock payment dummy & $\begin{array}{l}-1.64 \\
(0.02)\end{array}$ & $\begin{array}{l}-1.66 \\
(0.02)\end{array}$ & & \\
\hline Deal value & $\begin{array}{l}-3.33 \\
(0.00)\end{array}$ & $\begin{array}{c}2.81 \\
(\mathbf{0 . 0 5})\end{array}$ & & \\
\hline Observations & 632 & 632 & 606 & 606 \\
\hline $\mathbf{R}^{2}$ & 0.0568 & 0.0313 & 0.0511 & 0.0452 \\
\hline
\end{tabular}




\section{Panel B: Free Cash Flow Agency Problems and Earnings Manipulation}

In columns B1 and B2, probit regressions of a free cash flow "danger signal" dummy on the continuous independent director and CEO power measures IDC and CEOC, with controls and industry and year fixedeffects. The free cash flow "danger signal" dummy is set to one if the firm's cash flow exceeds its FamaFrench 17-industry (FF-17) median, its dividend payout is below its FF-17 median, and its Tobin's Q is below its FF-17 median; and to zero otherwise. In columns B3-B6, OLS regressions explain the absolute value of the modified Jones model discretionary accruals with the continuous measure of powerful independent board IDC and their analogs for a powerful independent audit committee, IDCA. All regressions include control variables and industry and year fixed-effects. Sample is 13,933 firm-years of S\&P 1500 firms from 1999 to 2010. Numbers in parentheses are robust p-levels clustering by firm. Boldface denotes significance at $10 \%$ or better.

\begin{tabular}{|c|c|c|c|c|c|c|}
\hline Regression & A7B.1 & A7B.2 & A7B.3 & A7B.4 & A7B.5 & A7B.6 \\
\hline Explained & \multicolumn{2}{|c|}{ Free Cash Flow } & \multicolumn{4}{|c|}{ Earning Management (EM) } \\
\hline Power $=$ & $I D C$ & $I D C$ & IDC & $I D C A$ & IDC & $I D C A$ \\
\hline Power & $\begin{array}{r}-0.007 \\
(0.00)\end{array}$ & $\begin{array}{c}-\mathbf{0 . 0 0 7 9 7} \\
(0.00)\end{array}$ & $\begin{array}{c}-0.00026 \\
(0.00)\end{array}$ & $\begin{array}{c}-\mathbf{- 0 . 0 0 0 2 1} \\
(0.00)\end{array}$ & $\begin{array}{c}-\mathbf{0 . 0 0 0 1 7} \\
(0.05)\end{array}$ & $\begin{array}{c}-\mathbf{- 0 . 0 0 0 1 4} \\
(0.06)\end{array}$ \\
\hline CEOC & & $\begin{array}{c}0.00134 \\
(0.54)\end{array}$ & & & $\begin{array}{c}-0.00014 \\
(0.04)\end{array}$ & $\begin{array}{c}-\mathbf{0 . 0 0 0 1 5} \\
(0.02)\end{array}$ \\
\hline $\log (C E O$ age $)$ & $\begin{array}{c}0.0768 \\
(0.74)\end{array}$ & $\begin{array}{c}0.0708 \\
(0.76)\end{array}$ & $\begin{array}{l}0.0251 \\
\mathbf{( 0 . 0 0 )}\end{array}$ & $\begin{array}{c}0.0259 \\
\mathbf{( 0 . 0 0 )}\end{array}$ & $\begin{array}{c}0.0255 \\
\mathbf{( 0 . 0 0 )}\end{array}$ & $\begin{array}{c}0.0259 \\
\mathbf{( 0 . 0 0 )}\end{array}$ \\
\hline loo (hoard size) & 0.089 & 0.0847 & 0.00402 & 0.00393 & 0.00424 & 0.00425 \\
\hline & $(0.54)$ & $(0.56)$ & $(0.38)$ & $(0.39)$ & $(0.36)$ & $(0.35)$ \\
\hline e-index & $\begin{array}{c}-0.0171 \\
(0.53)\end{array}$ & $\begin{array}{c}-0.0174 \\
(0.53)\end{array}$ & $\begin{array}{c}-0.000144 \\
(0.84)\end{array}$ & $\begin{array}{c}-0.000169 \\
(0.81)\end{array}$ & $\begin{array}{c}-0.0000479 \\
(0.95)\end{array}$ & $\begin{array}{c}-0.000048 \\
(0.95)\end{array}$ \\
\hline $\log$ (total assets) & $\begin{array}{c}0.0189 \\
(0.48)\end{array}$ & $\begin{array}{c}0.0164 \\
(0.54)\end{array}$ & $\begin{array}{c}0.00139 \\
(0.19)\end{array}$ & $\begin{array}{c}0.00117 \\
(0.25)\end{array}$ & $\begin{array}{c}0.00176 \\
(0.10)\end{array}$ & $\begin{array}{c}0.0017 \\
(0.11)\end{array}$ \\
\hline book leverage & $\begin{array}{c}-0.393 \\
(0.04)\end{array}$ & $\begin{array}{l}-0.399 \\
(0.04)\end{array}$ & $\begin{array}{l}0.0037 \\
(0.64)\end{array}$ & $\begin{array}{c}0.00357 \\
(0.65)\end{array}$ & $\begin{array}{c}0.00377 \\
(0.63)\end{array}$ & $\begin{array}{c}0.00364 \\
(0.65)\end{array}$ \\
\hline profitability & $\begin{array}{c}-0.541 \\
(0.12)\end{array}$ & $\begin{array}{l}-0.553 \\
(0.12)\end{array}$ & $\begin{array}{c}0.0658 \\
\mathbf{( 0 . 0 0 )}\end{array}$ & $\begin{array}{c}0.0658 \\
\mathbf{( 0 . 0 0 )}\end{array}$ & $\begin{array}{c}0.0651 \\
\mathbf{( 0 . 0 0 )}\end{array}$ & $\begin{array}{l}0.065 \\
\mathbf{( 0 . 0 0 )}\end{array}$ \\
\hline investment & $\begin{array}{l}1.006 \\
(0.02)\end{array}$ & $\begin{array}{l}1.015 \\
(0.01)\end{array}$ & $\begin{array}{l}-0.117 \\
\mathbf{( 0 . 0 0 )}\end{array}$ & $\begin{array}{l}-0.116 \\
\mathbf{( 0 . 0 0 )}\end{array}$ & $\begin{array}{l}-0.119 \\
\mathbf{( 0 . 0 0 )}\end{array}$ & $\begin{array}{l}-0.118 \\
\mathbf{( 0 . 0 0 )}\end{array}$ \\
\hline $\mathbf{R}^{2}$ & 0.0494 & 0.0497 & 0.0383 & 0.0381 & 0.0388 & 0.0388 \\
\hline
\end{tabular}




\section{Appendix A8: Powerful Independent Directors and CEO Compensation}

CEO pay is equity, total or cash pay in Panels A, B and C, respectively. OLS regressions explain $\log (\mathrm{CEO}$ pay) with independent director power measures, the powerful independent board dummy PIB or continuous independent director power measure $I D C$ for the full board, or their analogs for the compensation committee, PIBC or IDCC, along with interactions of each with prior year total stock return, RET. All regressions control for logarithms of CEO age and board size, e-index, log of total assets, book leverage, profitability, investment, R\&D over total assets, and advertising expenses over total assets and include year and industry fixed-effects. Regressions 1 to. 4 in each panel control for the corresponding CEO power measure, either the powerful CEO dummy PCEO or continuous CEO power CEOC. Variables are described in Table 2. Sample is a 13,933 firm-year panel of S\&P 1500 firms from 1999 to 2010. Numbers in parentheses are robust p-levels clustering by firm. Boldface denotes significance at $10 \%$ or better.

Panel A: CEO Equity Compensation

\begin{tabular}{ccccccccc} 
Regression & A8A.1 & A8A.2 & A8A.3 & A8A.4 & A8A.5 & A8A.6 & A8A.7 & A8A.8 \\
\hline Ind. Director Power $=$ & PIB & PIBC & IDC & IDCC & PIB & PIBC & IDC & IDCC \\
CEO Power $=$ & PCEO & PCEO & CEOC & CEOC & & & & \\
\hline \multirow{2}{*}{ Ind. Director Power } & $\mathbf{0 . 7 3 6}$ & $\mathbf{0 . 9 2 2}$ & $\mathbf{0 . 0 3 6 1}$ & $\mathbf{0 . 0 3 3 5}$ & $\mathbf{0 . 9 1 7}$ & $\mathbf{1 . 0 7 9}$ & $\mathbf{0 . 0 4 7 5}$ & $\mathbf{0 . 0 4 1 1}$ \\
& $\mathbf{( 0 . 0 0 )}$ & $\mathbf{( 0 . 0 0 )}$ & $\mathbf{( 0 . 0 0 )}$ & $\mathbf{( 0 . 0 0 )}$ & $\mathbf{( 0 . 0 0 )}$ & $\mathbf{( 0 . 0 0 )}$ & $(\mathbf{0 . 0 0 )}$ & $(\mathbf{0 . 0 0 )}$ \\
Ind. Director Powder & $\mathbf{0 . 1 8 2}$ & $\mathbf{0 . 4 0 1}$ & $\mathbf{0 . 0 0 8 8}$ & $\mathbf{0 . 0 2 0 0}$ & 0.152 & 0.295 & 0.0076 & $\mathbf{0 . 0 1 5 6}$ \\
$\times$ RET & $\mathbf{( 0 . 4 8 )}$ & $\mathbf{( 0 . 0 5 )}$ & $\mathbf{( 0 . 3 5 )}$ & $\mathbf{( 0 . 0 6 )}$ & $(0.47)$ & $(0.14)$ & $(0.36)$ & $\mathbf{( 0 . 0 9 )}$ \\
CEO Power & $\mathbf{0 . 7 0 9}$ & $\mathbf{0 . 6 8 5}$ & $\mathbf{0 . 0 1 6 4}$ & $\mathbf{0 . 0 1 6 6}$ & & & & \\
& $\mathbf{( 0 . 0 0 )}$ & $\mathbf{( 0 . 0 0 )}$ & $\mathbf{( 0 . 0 0 )}$ & $\mathbf{( 0 . 0 0 )}$ & & & & \\
CEO Power $\times \boldsymbol{R E T}$ & -0.064 & -0.205 & -0.002 & -0.006 & & & & \\
& $(0.82)$ & $(0.38)$ & $(0.85)$ & $(0.43)$ & & & & \\
RET & 0.0778 & 0.0624 & -0.434 & -1.034 & 0.0648 & 0.038 & -0.46 & -1.141 \\
$\boldsymbol{R}^{2}$ & $(0.33)$ & $(0.51)$ & $(0.50)$ & $(0.16)$ & $(0.42)$ & $(0.71)$ & $(0.45)$ & $(0.12)$ \\
\hline
\end{tabular}

Panel B: CEO Total Compensation

\begin{tabular}{|c|c|c|c|c|c|c|c|c|}
\hline Regression & A8B.1 & A8B.2 & A8B.3 & A8B.4 & A8B.5 & A8B.6 & A8B.7 & A8B.8 \\
\hline Ind. Director Power = & $P I B$ & $P I B C$ & $I D C$ & $I D C C$ & $P I B$ & $P I B C$ & $I D C$ & $I D C C$ \\
\hline CEO Power $=$ & PCEO & PCEO & CEOC & CEOC & & & & \\
\hline Ind. Director Power & $\begin{array}{l}0.208 \\
(0.00)\end{array}$ & $\begin{array}{l}0.215 \\
(0.00)\end{array}$ & $\begin{array}{c}0.0103 \\
(0.00)\end{array}$ & $\begin{array}{c}0.0073 \\
(0.00)\end{array}$ & $\begin{array}{r}0.256 \\
(0.00)\end{array}$ & $\begin{array}{l}0.258 \\
(0.00)\end{array}$ & $\begin{array}{c}0.0145 \\
(0.00)\end{array}$ & $\begin{array}{c}0.0104 \\
(0.00)\end{array}$ \\
\hline $\begin{array}{c}\text { Ind. Director Powder } \\
\times R E T\end{array}$ & $\begin{array}{l}0.0796 \\
(0.14)\end{array}$ & $\begin{array}{l}0.0501 \\
(0.35)\end{array}$ & $\begin{array}{l}0.0008 \\
(0.76)\end{array}$ & $\begin{array}{l}-0.002 \\
(0.31)\end{array}$ & $\begin{array}{r}0.059 \\
(0.31)\end{array}$ & $\begin{array}{l}0.0398 \\
(0.53)\end{array}$ & $\begin{array}{l}-0.000 \\
(0.95)\end{array}$ & $\begin{array}{l}-0.002 \\
(0.26)\end{array}$ \\
\hline CEO Power & $\begin{array}{l}0.189 \\
(0.00)\end{array}$ & $\begin{array}{l}0.191 \\
(0.00)\end{array}$ & $\begin{array}{c}0.0060 \\
(0.00)\end{array}$ & $\begin{array}{r}0.0069 \\
(0.00)\end{array}$ & & & & \\
\hline CEO Power $\times$ RET & $\begin{array}{l}-0.041 \\
(0.52)\end{array}$ & $\begin{array}{l}-0.023 \\
(0.70)\end{array}$ & $\begin{array}{l}-0.001 \\
(0.45)\end{array}$ & $\begin{array}{c}0.0001 \\
(0.95)\end{array}$ & & & & \\
\hline$R E T$ & $\begin{array}{l}0.100 \\
(0.01)\end{array}$ & $\begin{array}{l}0.107 \\
(0.01)\end{array}$ & $\begin{array}{c}0.15 \\
(0.47)\end{array}$ & $\begin{array}{l}0.254 \\
(0.15)\end{array}$ & $\begin{array}{r}0.0949 \\
(0.01)\end{array}$ & $\begin{array}{l}0.103 \\
(0.01)\end{array}$ & $\begin{array}{l}0.126 \\
(0.54)\end{array}$ & $\begin{array}{l}0.275 \\
(0.08)\end{array}$ \\
\hline$R^{2}$ & 0.281 & 0.281 & 0.29 & 0.289 & 0.277 & 0.277 & 0.286 & 0.284 \\
\hline
\end{tabular}


Panel C: CEO Cash Compensation

\begin{tabular}{ccccccccc} 
Regression & A8C.1 & A8C.2 & A8C.3 & A8C.4 & A8C.5 & A8C.6 & A8C.7 & A8C.8 \\
\hline Ind. Director Power $=$ & PIB & PIBC & IDC & IDCC & PIB & PIBC & IDC & IDCC \\
CEO Power $=$ & PCEO & PCEO & CEOC & CEOC & & & & \\
\hline \multirow{2}{*}{ Director Power } & $\mathbf{0 . 0 4 8 6}$ & $\mathbf{0 . 0 7 5 7}$ & 0.0027 & $\mathbf{0 . 0 0 3 0}$ & $\mathbf{0 . 0 6 8 2}$ & $\mathbf{0 . 0 9 2}$ & $\mathbf{0 . 0 0 4 3}$ & $\mathbf{0 . 0 0 3 9}$ \\
& $\mathbf{( 0 . 0 6 )}$ & $\mathbf{( 0 . 0 0 )}$ & $(0.11)$ & $\mathbf{( 0 . 0 1 )}$ & $\mathbf{( 0 . 0 1 )}$ & $\mathbf{( 0 . 0 0 )}$ & $\mathbf{( 0 . 0 0 )}$ & $(\mathbf{0 . 0 0 )}$ \\
Ind. Director Powder & 0.0011 & -0.001 & 0.0001 & -0.002 & 0.0109 & 0.0106 & 0.0001 & -0.001 \\
$\times$ RET & $(0.98)$ & $(0.98)$ & $(0.97)$ & $(0.11)$ & $(0.83)$ & $(0.84)$ & $(0.97)$ & $(0.38)$ \\
CEO Power & $\mathbf{0 . 0 7 7 4}$ & $\mathbf{0 . 0 7 2 4}$ & $\mathbf{0 . 0 0 2 3}$ & $\mathbf{0 . 0 0 2 1}$ & & & & \\
& $\mathbf{( 0 . 0 1 )}$ & $\mathbf{( 0 . 0 2 )}$ & $\mathbf{( 0 . 0 7 )}$ & $\mathbf{( 0 . 0 6 )}$ & & & & \\
CEO Power $\times$ RET & 0.0176 & 0.0183 & 0.000 & 0.001 & & & & \\
& $(0.71)$ & $(0.69)$ & $(1.00)$ & $(0.52)$ & & & & \\
RET & $\mathbf{0 . 0 6 3 1}$ & $\mathbf{0 . 0 6 3 9}$ & 0.0614 & 0.14 & $\mathbf{0 . 0 6 3 6}$ & $\mathbf{0 . 0 6 4 5}$ & 0.0618 & 0.169 \\
$\boldsymbol{R}^{2}$ & $\mathbf{( 0 . 0 3 )}$ & $\mathbf{( 0 . 0 3 )}$ & $(0.71)$ & $(0.32)$ & $\mathbf{( 0 . 0 3 )}$ & $\mathbf{( 0 . 0 2 )}$ & $(0.70)$ & $(0.15)$ \\
\hline & 0.189 & 0.19 & 0.19 & 0.191 & 0.188 & 0.189 & 0.19 & 0.191
\end{tabular}

